\title{
Wildfires, soil carbon balance and resilient organic matter in Mediterranean ecosystems. A review
}

\author{
Los incendios forestales, el balance de carbono en el suelo y la materia orgánica resiliente \\ en ecosistemas mediterráneos. Una revision \\ Incêndios florestais, balanço do carbono no solo e matéria orgânica resiliente em \\ ecossistemas mediterrânicos. Uma revisâo
}

\section{AUTHORS}

\section{Almendros G.@1 \\ humus@ccma.csic.es}

\section{González-Vila}

F.J. ${ }^{2}$

\section{@ Corresponding \\ Author}

${ }^{1}$ National Museum of Natural Sciences (CSIC). Humus Chemistry Lab. Serrano 115 dpdo. 28006 Madrid (Spain).

${ }^{2}$ Instituto de Recursos Naturales y Agrobiología (CSIC), Av. Reina Mercedes, 10. 41012 Sevilla (Spain).
Received: 11.06.2012 | Revised: 02.07.2012 | Accepted: 03.07.2012

\section{ABSTRACT}

A review of the effects of wildfires on Mediterranean soils was carried out with special emphasis on the biogeochemical processes involved in soil $\mathrm{C}$ sequestration. Modifications to the composition and properties of soil humic substances and related resilient $\mathrm{C}$-forms in soil resulting from fires were also discussed. The systematic effects of fires on soil organic matter (SOM) mainly involve changes to its solubility and colloidal properties, selective thermal degradation, structural condensation and the cyclization of soil $\mathrm{C}$ and $\mathrm{N}$-forms. These effects represent an increase in the biogeochemical stability and chemical diversity of the SOM after the thermal generation of structures that are not found in soils unless they are affected by fire. Non-systematic effects also depend on local environmental constraints and on the great differences in fire intensities and propagation patterns. The effects of fire were also discussed, taking advantage of the results of laboratory simulation experiments. This approach is indispensable for differentiating fire intrinsic effects on soil from those produced by fire-induced inputs of charred necromass and the subsequent effects of soil erosion. In some cases, the characteristic properties acquired by post-fire soils can be explained in terms of molecular-level features of humic substances and, in particular, those concerning resistance to biodegradation, cation exchange capacity, $\mathrm{N}$-availability, soil water repellence and aggregate stability.

\section{RESUMEN}

En este trabajo se lleva a cabo una revisión sobre los efectos de los incendios forestales en los suelos mediterráneos, con especial énfasis sobre sus efectos en los procesos biogeoquimicos de acumulación o secuestro de $C$ en el suelo. Asimismo, se revisan los efectos de los incendios sobre la composición y propiedades de las sustancias húmicas y otras formas resilientes de $C$ en el suelo. Las principales efectos sistemáticos del fuego sobre la materia orgánica incluyen cambios en su solubilidad y propiedades coloidales, así como degradación térmica selectiva, condensaciones estructurales y ciclación de formas de $C$ y $N$ en el suelo. Estos efectos, en conjunto, se consideran responsables del aumento en la diversidad quimica de la materia orgánica debido a la generación térmica de nuevos compuestos inexistentes en los correspondientes suelos no afectados por el fuego. Además de ello, deben considerarse los efectos no sistemáticos del fuego, que dependen de las condiciones ambientales locales y la amplia diversidad de los tipos de incendios. También se discuten los resultados de estudios sobre efectos del fuego en experimentos de simulación en laboratorio, que constituyen una aproximación experimental indispensable para diferenciar los efectos intrinsecos de los incendios en el suelo de aquellos producidos por aportes de necromasa carbonizada. Finalmente, se revisan los efectos del fuego en la estructura molecular de las sustancias humicas, que pueden ser asociadas con cambios en las propiedades de los suelos, en particular respecto a la resistencia a la biodegradación, capacidad de intercambio catiónico, disponibilidad de $N$, repelencia al agua y estabilidad de los agregados del suelo. 


\section{RESUMO}

Neste estudo faz-se uma revisão dos efeitos dos incêndios florestais nos solos mediterrânicos dando particular enfase aos efeitos nos processos biogeoquimicos de acumulação e sequestro de $C$ no solo. Por outro lado, revem-se os aspectos relacionados com os efeitos dos incêndios sobre a composiçẫo e propriedades das substâncias húmicas e outras formas resilientes de $C$ no solo. Os principais efeitos sistemáticos do fogo sobre a matéria orgânica incluem alteraçôes da sua solubilidade e propriedades coloidais, bem como degradaçẫo térmica selectiva e condensação e ciclagem das formas de $C$ e $N$ no solo. Estes efeitos representam um aumento da estabilidade biogeoquímica e da diversidade química da matéria orgânica do solo devido à formação térmica de novas estruturas e compostos inexistentes nos solos não afectados pelos fogos. Para além disso, consideram-se os efeitos não-sistemáticos dos fogos, que dependem das condiçôes ambientais locais bem como da grande diferença de intensidade dos fogos e padrôes da sua propagação. Apresentam-se também resultados sobre o efeito dos fogos em ensaios de simulação laboratorial, que constituem uma abordagem experimental indispensável para distinguir os efeitos intrísecos dos incêndios dos produzidos devido a inputs no solo de necromassa carbonizada. Finalmente, faz-se uma revisão dos efeitos do fogo na estrutura molecular das substâncias húmicas associados a alteraçôes nas propriedades do solo, particularmente no que se refere à resistência à biodegradação, capacidade de troca catiónica, disponibilidade de $N$, caracteristícas hidrofóbicas e estabilidade dos agregados do solo.

KEYWORDS

Humic substances, thermal impact, burnings, soil carbon sequestration

PALABRAS

CLAVE

Sustancias húmicas, impacto térmico, quemas, secuestro de carbono en el suelo

PALAVRAS-

CHAVE

Substâncias húmicas, impacto térmico, queimadas, sequestro de carbono no solo 


\section{Introduction}

On a planetary scale, it has been estimated that between 530 and $555 \times 10^{6}$ ha of forest lands are affected by fire every year, causing losses of about $50 \mathrm{Pg} \mathrm{yr}^{-1}$ of biomass (Levine 1996). In addition fire has severe effects on terrestrial ecosystems, which are reflected in soil health and ecosystem stability. The subsequent soil loss associated with erosive processes is frequently considered to be the most severe environmental perturbation caused by wildfires in terms of C exportation from the ecosystem (Certini 2005; Bowman et al. 2009).

Early investigations (Almendros et al. 1990, 1992, 2003b; González-Vila and Almendros 2003; González-Pérez et al. 2004 and citations therein) have pointed out a number of direct or indirect molecular alterations, the most significant being the component of the SOM that is transformed into a recalcitrant organic substrate not readily recognized by specific enzymes in the soil. The effects of fire are comparable to several features of the biological maturation of SOM, a molecular diagenesis produced by enzymatic or abiotic processes usually taking hundreds or thousands of years. In many cases, low- and medium-intensity fires induce structural changes in SOM not readily distinguishable from those due exclusively to biotic soil processes (Almendros et al. 1990; Hernández and Almendros 2012).

When considering the importance of soil $\mathrm{C}$ in the global Earth's biogeochemical cycle, it is easy to understand the key importance of the above quantitative and qualitative alterations to the SOM, leading to the removal of a significant portion of $\mathrm{C}$ from the fast-turnover biogeochemical cycle.

Current trends in SOM research pay special attention to the quality rather than the quantity of C stored in soils (Almendros 2008a), a relevant approach considering that the Kyoto Protocol does not consider soil as a primary $\mathrm{C}$-sink. The above considerations justify the detailed assessment of SOM composition and structure. In particular, the molecular characterization of the SOM provides objective information on soil processes, quality and resilience, i.e., its poten- tial to remain unchanged against environmental impacts. Structural studies on SOM are also helpful in establishing the variable extent of the independent C-stabilization processes in the different types of soils. However, the systematic use of multianalytical approaches for these purposes is not frequent, since it requires timeconsuming preparative laboratory techniques as well as the availability of expensive instrumental techniques.

\section{Diversity of wildfires effects}

The history of fire and its management is also the history of human ecology adapted to fire, subjected to continuous changes as regards the prevailing paradigms on the origin and effects (catastrophic vs. chronic and even useful) of forest fires. Caldararo (2002) comprehensively reviewed the relationships between human activities and forest fires and concluded that in the present day frequent fires are a direct consequence of human forest management. Pyne (2001) addressed the fact that fires behave as part of the terrestrial ecosystems and have a determinant role in the structure of the landscapes associated with different human societies.

The impact of wildfires on the environment is commonly considered to be especially harmful, mainly due to the severe changes produced in physical and chemical properties of the soils (Giovannini and Lucchesi 1983; Tinoco 2000). However, the extent of fire effects on soils can be highly variable depending on the ecosystem; for example, the impact of fire on soil in a subhumid forest is very different to its impact on soil in a continental semiarid Mediterranean ecosystem. In general, subhumid forests accumulate thick $\mathrm{C}$ horizons mainly consisting of raw humus with biodegradable SOM, which would be rapidly exchanged with the atmospheric $C$ in a hypothetical climate change scenario with increased humidity and temperature. Conversely, the semiarid Mediterranean soils (comparatively resilient) contain a lower concentration of SOM 
but a comparatively longer residence time and higher humification degree. This stability would be favored by its formation under conditions of high seasonality with drastic soil drying-rewetting cycles leading to intense organo-mineral interactions. These are associated with structural condensation and diagenetic maturity of SOM with enhanced resistance to further biodegradation (Almendros et al. 1984a, 1984b, 1990).

Research taking advantage of experimental designs that compare the effects of natural fires with those of controlled fires (including smallscale heatings in laboratory conditions) could help to unravel the controversy over the variable effects of fires on the quality of the different forms of SOM. Some of these effects may be positive, at least regarding the biogeochemical cycles in certain soils. Although controlled burning of biomass wastes in the field is currently prohibited in many developed countries for obvious reasons of environmental health, fire as an agroforestry management tool is still used in many parts of the world. These include traditional slash \& burn practices for conversion of ecosystems or shrub forest areas into agriculture or livestock use, and may represent an interesting field to study the mechanisms leading to the stabilization of SOM as a result of heating (Almendros et al. 2003a).

\section{Wildfires and their interest for the scientific community}

The study of the effects of forest fires on the functioning of the soils is a current research line receiving increasing attention, given the relevant environmental impact of this phenomenon in certain phytosociological formations (marcescent forests and savannas) and in several geographic areas (Da Silva and Batalha 2008).

Amongst the research lines focused on the effects of forest fires in the soil system, the following topics could be emphasized:

- Wildfires and the ecological succession

- Fire, soil erosion and soil degradation
- Influence on surface and subsurface hydrological processes

- Fire and soil water-repellency

- Fire and soil structure and physical properties

- Fire and the accumulation of stable C-forms in the long-term (black-carbon, pyrogenic humus, etc)

- Molecular proxies of the effect of fire in SOM

- Soil biology of fire-affected ecosystems with regard to enzyme activity and soil microfauna

- Prescribed burnings and intentional forest fires and their bearing on land use

- Wildfires and release into the atmosphere of carcinogenic or mutagenic volatile compounds

The above broad subjects have led to proliferation of extensive literature and periodic international conferences on specific topics. These included a high-impact series of conferences such as "Forest Fires Research" and "Fire Ecology and Management", as well as specific workshops on the effects of forest fires, such as those included in conventions of the European Geosciences Union (EGU, Vienna, 2002-2012) in many conferences on environmental risks. There is a growing number of specific journals (Journal of Forest Fire Research, International Journal of Wildland Fire, Fire Safety, Fire and Materials, Fire Management Notes, etc) and a current trend for publishing articles on this topic in multidisciplinary journals on Ecology and Soil Sciences, Forestry and Environment. A large compendium of specialized papers is available from the monthly Current Titles and database at the Wildland Fire Research Institute of Arizona (http://www.fireresearchinstitute.org).

There are scientific societies in several countries including specialists in various aspects of the study of the effects of fire. This is the case with the Spanish network "Fuegored" (http:// grupo.us.es/fuegored) created in 2007 under the auspices of the Spanish Ministry of Science and Innovation, which has already held four national meetings (Valencia 2008, Seville 2009, Santiago de Compostela 2010, Tenerife 2012), published comprehensive books reviewing the large number of studies conducted 
by Spanish scientists on the effect of fire on soils (Cerdà and Mataix-Solera 2009), and produced monographic issues on specific methodological approaches and techniques appropriate to the study of the impact of wildfires (Cerdà and Jordán 2010). The growing interest in the specific effects of fires on soil is also evident from the series of FESP conferences (International Meetings of Fire Effects on Soil Properties) formerly held in Barcelona (Spain, 2007), with further editions in Marmaris (Turkey, 2009), Guimarães (Portugal, 2011) and Vilnius (Lithuania, 2013), that are contributing to the improved understanding of the fire issue and to the organization of the scientific community.

\section{A case study: the effect of fire on the $\mathrm{C}$ cycle in soils of Mediterranean ecosystems}

The incidence of fires is particularly frequent in countries with a Mediterranean climate, where fire is currently recognized as one of the main drivers in the structure and functioning of terrestrial ecosystems. Fire is also considered the disturbing factor that most influences the composition, type, goods and services provided by the ecosystems (Richardson 1998 and references therein). To large extent, this is due to peculiar characteristics of the semi-arid Mediterranean climate, such as:

1. A hot and dry season with a soil water deficit which determines a contrasting seasonal biogoechemical activity. In some cases this leads to the enzymatic soil processes of biodegradation and humification being active only for two to three months of the year, a limitation which is also reflected by a slow C flow and a suboptimum release of the nutrients required for recharging the soil solution (Almendros et al. 2008)

2. Under the above conditions, fire is a recurrent agent with long-term effects on the humification processes and biogeochemical performance.
It forces a temporary replacement of the slowgrowth vegetation by post-fire vegetation in few months, at expense of the release of nutrients from the ash. In soils not affected by post-fire erosive phenomena, however, the amounts of humified C-forms may remain constant or even increase to a variable extent.

3. The biomass of many typical Mediterranean plant species is self-combustible due to their low water content and relatively high concentration of essential oils. In addition, Mediterranean vegetation frequently consists of pyrophyte plant species with anatomical or physiological pre-adaptations to withstand fires. Concerning this fact, ecologists often consider that pyrophytes, in addition to marcescent forest (i.e., trees with senescent leaves, remaining attached to the branches until spring) are factors that invite wildfire in Mediterranean environments and could represent outstanding ecophysiological adaptive advantages in ecosystems where the biological nutrient recycling is a limiting factor.

4. Ecosystems with characteristically high biological activity (e.g., rainforest) may have a zero or negative balance with regard to the accumulation of soil $\mathrm{C}$, due to its active $\mathrm{C}$ turnover and the fact that atmospheric $C$ is sequestered in biomass more than in soil. This is not the case with semi-arid ecosystems, where the accumulation of "black carbon" and recalcitrant SOM not amenable to enzymatic degradation (from past fires) are abiotic processes largely contributing to SOM stabilization. The above-indicated stable organo-mineral interactions favored by drying-rewetting cycles contribute to this process (Borken and Matzner 2009).

5. Complex socio-economic factors also contribute to the proliferation of fires in some scenarios. The reasons are varied and include:

a. Maintenance of traditional practices based on burning of forest waste, stubble and other crop residues.

b. Migration of the rural population, associated with abandonment of croplands and further bush encroachment, which in Medi- 
terranean countries favours the occurrence of fires. This has also led to the abandonment of traditional sustainable management practices of silvopastoral systems that contributed to controlled extraction of forest fuel.

c. The intentional cause of a large percentage of fires, over $50 \%$ in Spain and about 30\% in the Mediterranean area (Spanish Ministry of Environment 2005).

\section{Research on recovery indexes of fire-affected soils}

Monitoring the effects of fires on soil properties is required to design successful strategies for rehabilitation and restoration of burned areas. In this sense, most of the current research on the impact of fire on soil focuses on the alteration of SOM, with particular emphasis paid to the molecular-level analysis of the various forms of soil $\mathrm{C}$, particularly the so-called humic substances (recalcitrant polydispersed and polyfunctional, three-dimensional quasi-chaotic structures, formed in the soils and not synthesized by living organisms). Humic substances comprise the humic acids (acid-insoluble, alkali-soluble), fulvic acids (acid- and alkali-soluble) and humin (insoluble, linked to minerals). As a whole, humic substances represent the major forms of stabilized $C$ in soil and sediments (Aiken et al. 1985; Schnitzer and Khan 1978; Stevenson 1982; Almendros 2008b).

So far, studies on SOM have contributed to a 'neutral view' of fires as a soil forming factor: not considered as a progressive or regressive factor in the evolution of ecosystems, but leading to scale-dependent effects which vary in terms of local conditions. The effect of fire is primarily topographic given its importance in the erosion of surface horizons, but in flat areas it is responsible for significant changes in the dynamics of soil C (Cerdà 2004). It is well known that the carbon cycle after forest fires can be severely affected by the high soil erosion rates. Longterm experiments show that fires form part of the geomorphological system, since the recovery of previous soil erosion rates may take a number of years, depending on vegetation coverage, vegetation type, and its effect on soil hydrophobicity (Cerdà and Doerr 2005).

Fire is an abiotic factor with a clear impact on the molecular record in the SOM. The study of fire-induced changes is therefore a subject of interest for the correct interpretation of soil health and the quality of ecosystems, which are reflected in the chemical composition of SOM, mainly lipids and humic substances (Arias et al. 2005).

Studies on SOM alteration by the fire also have a practical purpose, since the molecular composition of humic substances can be used as a source of information on the impact and potential recovery of soils affected by forest fires (González-Vázquez 2011). Nevertheless, studies focusing on the identification of molecular descriptors or proxies of the impact or intensity of fires in the past do not provide straightforward qualitative or quantitative indexes of immediate diagnostic value for the different ecosystems. As indicated below, fire shares too many effects in common with biological humification processes. The proxies frequently indicated in the literature are unspecific. This is the case with, for example, the formation of benzenecarboxylic acids, the generation of furfural, the cyclization of the amide forms of $\mathrm{N}$, the cleavage or insolubilization into nonextractable forms of perylenequinones (Tinoco et al. 2006; Almendros et al. 2010a). Recently, it has been proven that in the case of soil lipids, changes in $\mathrm{C}$ preference index (ratio of alkyl molecules with odd-to-even number of $\mathrm{C}$ atoms) in addition to shortening in the average length of alkyl chains (mainly in straight-chain $n$-hydrocarbons and fatty acids) could also be valid surrogates of the degree of alteration and potential recovery of soils affected by fires (Dettweiler et al. 2003a, 2003b; Kuhn et al. 2010). 


\section{Revisiting fire-induced molecular-level changes in soil organic matter}

1. Fires' impact on the soil $C$ cycle through its selective effects on young and matured organic matter fractions

Earlier studies on the impact of fires on SOM revealed an enhanced stability against biodegradation of the organic $\mathrm{C}$-forms in post-fire soils. For instance, much of the fire-induced C-loss is accounted for in the case of the free organic matter, which consists of non-decomposed organic particles, and the fulvic acid fraction of comparatively low polymerization extent and high $\mathrm{O}$ content. Both fractions tend to decrease preferentially after the fire. Conversely, a relative increase was observed both in the amount of particulate SOM protected in soil aggregates, and in the humic acid and the "non-extractable insolubilized humin' consisting of condensed humic acid-type fractions more or less tightly associated with the clay-size mineral soil fraction (Almendros et al. 1984a). These results are consistent with the empirical assumption in humus chemistry that the organic fractions more resistant to biodegradation are also those more resistant to laboratory degradation by thermal or wet chemical methods.

Several studies coincide in pointing out that the total amount of humic-type SOM fractions does not necessarily decrease after the impact of most types of fires. In organic soils the humic substances (in particular humic acids) tend to accumulate, which leads to changes in the type of humus, with up to eightfold increases in the humus reserves having been reported in postfire soils (Efremova and Efremov 2006).

2. Intrinsic and extrinsic factors explaining the variability of fire-induced changes

The assessment of systematic impacts of forest fires on the stability of SOM is largely limited by the wide variability of natural fires (e.g., fire propagation patterns and heat transfer types, final temperatures and exposition times of different kinds of biomass - self-combustible or not-, soil moisture, etc.). In addition, the limitation of any experimental approach on the effect of wildfires is the fact that the post-fire SOM is the combined result of changes in the chemical composition of the original SOM and consider- able inputs of charred biomass coming from partially burnt vegetation. This does not necessarily consist of charred organic matter, charcoal or 'black carbon', but frequently includes fresh biomass consisting mainly of woody tissues and/or herbaceous material, and is particularly the case with underground biomass such as plant roots. These, in most cases, are practically unaffected by the direct thermal effect and is incorporated into soil as dead fresh biomass. Depending on the inputs of the non-humic organic matter, charred or not, certain types of fires may lead to accumulation of raw humus-young organic matter-and may even represent a significant increase in total soil $\mathrm{C}$ levels. In this complex scenario, laboratory simulation of the effects of fires by progressive heating of soil samples at increasing temperatures and/or heating times is required to differentiate fire intrinsic effects from those ascribed to the inputs of charred residues or fresh biodegradable necromass (Almendros et al. 1984b, 1988; Knicker et al. 2006a).

Laboratory experiments on the "intrinsic effects" of fire demonstrated that, apart from the perturbation represented by plant necromass, massive inputs of the 'pyromorphic humus' in the soil $\mathrm{C}$ cycle present a series of specific characteristics irrespective of the fire and the vegetation type. These include aromatization, loss of oxygen-containing functional groups mainly by decarboxylation, structural condensation after dehydration with enhanced resistance against further chemical and enzymatic degradation, and an increase in the relative proportion of heterocyclic $\mathrm{N}$-forms (Almendros et al. 1984b). These changes in general depend on the intensity of the thermal impact, since moderate charring may led to oxidation of the organic matter and the concentration of all types (amide, heterocyclic) of organic $\mathrm{N}$-forms (Orioli and Curvetto 1978; Almendros et al. 1985). Evidence for the alternative increase in oxygen-containing structures in humic substances after moderate heating was obtained from ${ }^{13} \mathrm{C}$ NMR studies under quantitative acquisition conditions. This suggests an enhanced carboxyl-C content of post-fire organic matter which is compatible with the occurrence of oxidation reactions during - or very shortly after-the fire (Knicker et al. 2006a). 
The physico-chemical surrogate descriptors more readily reflecting the above structural, fireinduced changes should be: the increase in soil water repellency, the decrease in the $\mathrm{C} / \mathrm{N}$ ratio, the increase in optical density of all humic fractions, the decreased extractability (in alkaline solutions) of the SOM, and the progressive decrease — in the infrared spectra — of alkyl stretching and bending bands indicating selective depletion of aliphatic C-forms. The latter SOM constituents include carbohydrate (Martín et al. 2009), cutans, suberans and extractable lipids, in addition to the less structurally condensed aliphatic domains in humic fractions, which often represent up to $50 \%$ of the total constituents (Almendros et al. 1989a).

At the molecular level, and exclusively considering the intrinsic fire effects (excluding the incorporation of external biomass), chemical degradation, pyrolysis techniques and spectroscopic data show: a) the selective thermal degradation of the most labile SOM forms (mainly oxygen-containing), and b) the thermal distillation of volatile aliphatic compounds (alkanes, alkene-generating structures, fatty acids) that may represent either pre-existent free lipid fractions or products generated during pyrolysis or 'cracking' of the aliphatic domains of the humic substances (Almendros et al. 1984a; Rovira et al. 2012). When the structure of humic substances is studied by alkaline permanganate oxidation, for example, which is a classical method to compare relative amounts of structural components in SOM (Matsuda and Schnitzer 1972), a progressive quantitative decrease in $\alpha, \omega$-alkanedioic acids with the fire intensity is observed. The yields of alkanes and fatty acids remain relatively stable, especially in the case of compounds with cyclic and branched chains. There is also a typical demethoxylation of lignin-derived phenolic acids at the advanced heating stages, which lead to a relative increase in the yield of benzenecarboxylic acids after oxidative degradation. The latter compounds have even been postulated to be surrogates of the occurrence of black carbon in soils (Glaser et al. 1998).
3. Quantitative rearrangement in the different humic fractions resulting from the effects of fire

The modification of the colloidal properties of SOM is probably one out of the most marked effects of fire (González-Vila and Almendros 2003; Iglesias et al. 2008) since it is straightforwardly reflected both in the cation exchange capacity and the stability of soil organo-mineral complexes.

Despite the environmental relevance of the chemical properties of post-fire humic substances, both field and laboratory experiments are based on excessively complex systems which only provide limited information on the effect of thermal impact on SOM. Alternatively, laboratory experiments using 'reconstructed soil samples' of organic matter-free mineral substrates with added isolated humic or fulvic acids (Almendros et al. 1990), suggest rapid decarboxylation and dehydration reactions leading to striking changes in the hydrophobicity and speciation status of all SOM forms (Figure 1). In fact, the different humic fractions are operationally defined in terms of laboratory protocols based on their solubility (in acid or alkaline $\mathrm{pH}$ ). The experiments with reconstructed soils with isolated humic substances (Almendros et al. 1990) demonstrate that fire-affected organic matter systematically follows thermal diagenetic paths in which fulvic acids turn into an alkali-insoluble humic-acid type substance (Figure 2). With the progress of heating, the above substances lead to acid-and alkali-insoluble, humin-like fractions and, after severe heating, to a black-carbon-like material (here defined as heavily condensed black residue which resists even alkaline permanganate oxidation in laboratory conditions). This is consistent with the quantitative decreases in humic and fulvic fractions found after natural fires (Vergnoux et al. 2011).

Results of laboratory heating of the 'reconstructed soil samples' with isolated fulvic acids as the sole type of SOM showed that this mixture is transformed after few seconds of heating (e.g., 120 $\mathrm{sec}$ at $350^{\circ} \mathrm{C}$ with sample size $5 \mathrm{~g}$ ) into complex mixtures of all types of humic substances with increased stability against chemical and biological 


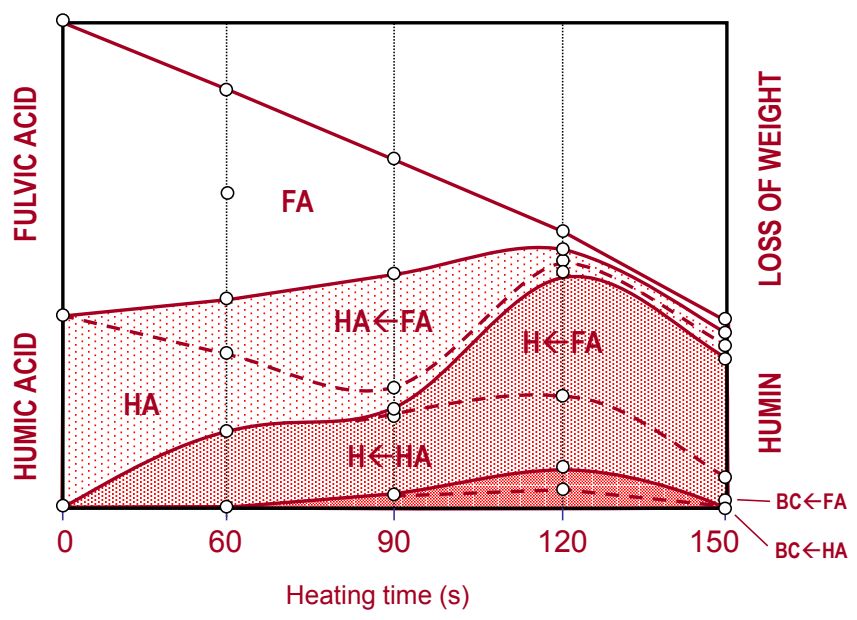

Figure 1. Evolution of major humic organic fractions in 'reconstructed soil samples' consisting of isolated humic substances from forest soil under holm oak and the corresponding mineral fraction. Samples were subjected to laboratory isothermal heating at $350^{\circ} \mathrm{C}$ for progressive periods. Vertical axis units correspond to the percentage of total soil humic carbon.

FA: fulvic acids which remain unaltered

$H A$ : humic acids which remain unaltered

$\mathrm{HA} \leftarrow$ FA: HA-like fraction formed during the heating of FA

$\mathrm{H} \leftarrow \mathrm{FA}$ and $\mathrm{H} \leftarrow \mathrm{HA}$ : humin-like fraction formed by the heating of either FA or $\mathrm{HA}$, respectively

$\mathrm{BC} \leftarrow \mathrm{FA}$ and $\mathrm{BC} \leftarrow \mathrm{HA}$ : black carbon fraction formed by the heating of either FA or HA

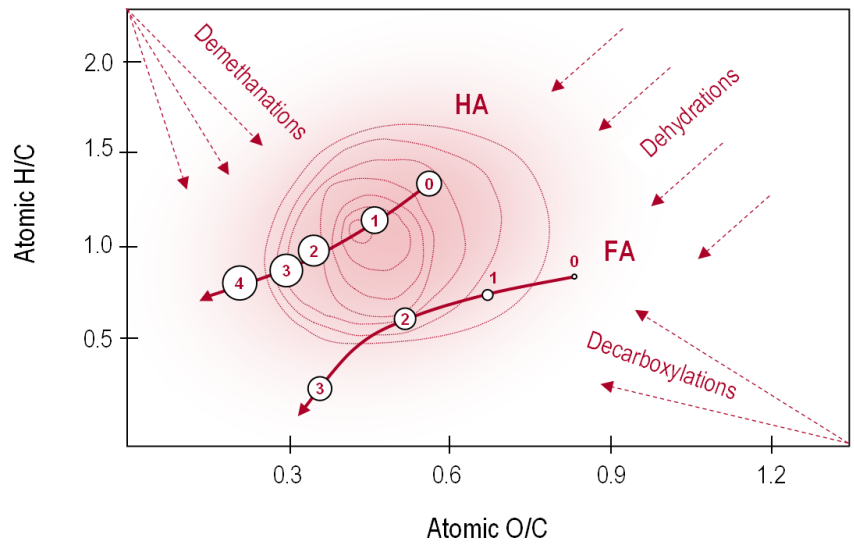

Figure 2. Changes in elementary composition $(\mathrm{H} / \mathrm{C}$ and $\mathrm{O} / \mathrm{C}$ atomic ratios, Van Krevelen's diagram) of humic acids (HA) and fulvic acids (FA) isolated from soil under holm oak and subjected to laboratory isothermal heating at $350{ }^{\circ} \mathrm{C}$ for progressive periods ranging from 60 (1) to 150 seconds (4). Arrows show the progress of classical reactions indicated in the plot. The size of the circles is proportional to the nitrogen content of the humic samples.

The data are plotted on a contour diagram that illustrates the natural variability (distribution and frequencies) of atomic ratios in humic acids, obtained from a large sample collection (ca. 300) of humic acids mainly obtained from Mediterranean soils. 
degradation. The same occurs in the case of reconstructed soils exclusively based on humic acid as the sole $\mathrm{C}$ source, where the evolution paths is in the same direction, i.e. formation of huminlike and black carbon-like fractions (Fernández et al. 2001). No quantitatively significant 'reverse evolution' towards a simpler material (e.g., fulvic acid-type) was observed, which could have been expected from depolymerization or thermal breakdown reactions (Almendros et al. 1989a, 2003b).

These experiments support the above-indicated increase in structural complexity induced by thermal processes. The decrease in solubility is presumably due to the removal of oxygencontaining functional groups, and probably accompanied by free-radical condensation of the C-backbone where the structural stability and resistance to chemical and biological degradation are enhanced and the molecular size progressively increased. Laboratory incubation experiments in addition to the determination of the atomic $\mathrm{H} / \mathrm{C}$ and $\mathrm{O} / \mathrm{C}$ ratios of the isolated humic substances isolated after heating the 'reconstructed' soil samples indicate that their stoichiometry, solubility properties and spectroscopic characteristics (visible and infrared spectra) can be difficult (if not impossible) to distinguish from the corresponding pre-existent humic fractions in the soil before thermal impact.

4. Selective degradation simultaneous to thermal neoformation of soil organic matter structures

In spite of the destructive effects expected in the case of severe thermal impact, most types of fires or laboratory heating of soil samples showed a typical enhancement in the complexity of the molecular assemblages released by analytical laboratory degradation of the SOM. Fireinduced reactions typically lead to the generation of aromatic structures from aliphatic precursors in humic substances (probably carbohydrate or carbohydrate-derived i.e, O-alkyl constituents), and induce complex rearrangements of the structure of free lipid compounds (Almendros et al. 1988) that are mainly chain breakdowns with thermal diagenesis of cyclic biogenic con-

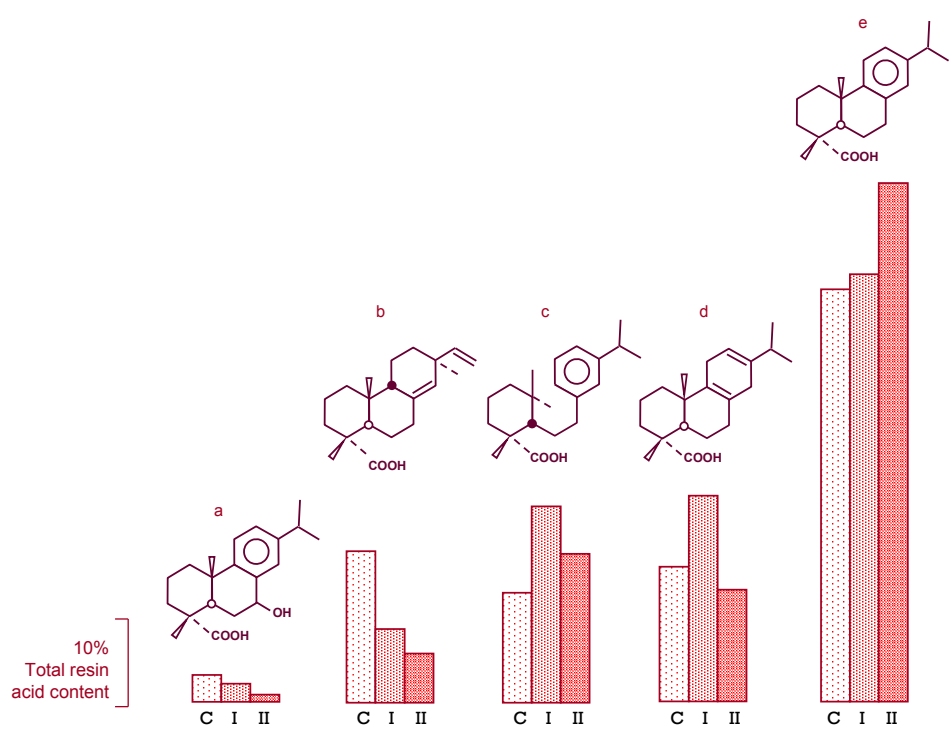

Figure 3. Relative proportion of the major resin acids in the lipid fraction of a soil under pine forest; C, control sample; I, II laboratory-heated whole soil samples heated at $160{ }^{\circ} \mathrm{C}$ (I) or at $210{ }^{\circ} \mathrm{C}$ (II). Compound numbers correspond to: (a) Methyl 7-hydroxydehydroabietate; (b) Methyl 8(14),15-pimaradien-18-oate; (c) Methyl 2S(2'(m-isopropylphenyl)ethyl)-IR,3S-dimethylcyclohexane-carboxylate; (d) Methyl 8,12-abietadien-18-oate; (e) Methyl 8,11,13-abietatrien-18-oate. 
stituents e.g., diterpene resin acids (Figure 3). In the case of the lipid fractions, several studies have confirmed that the homologous series of post-fire lipid fractions show an increased relative abundance of short-chain $\left(<\mathrm{C}_{20}\right)$ alkanes and fatty acids, and a convergence of the carbon preference index (ratio of even-to-odd Cnumbered chains) to close to unity (Almendros et al. 1988). These changes lead to a progressive smoothing of the biogenic signature: even$C$ numbered chains dominating in the case of fatty acids, and the opposite in alkanes due to the decarboxylation of fatty acids derived from higher plants. These changes (Figure 4) were confirmed in different types of soils (Dettweiler et al. 2003a, 2003b) and explain the fact that postfire lipids, which to a large extent could originally derive from epicuticular waxes of higher plants, frequently acquire characteristic features typical of fossil lipids and microbial lipids (i.e., dominance of homologues $<\mathrm{C}_{20}$ and no even-to-odd $\mathrm{C}$-number preference).

The considerable enhancement in the complexity of the molecular composition of the organic matter after heating is clearly shown in the case of carbohydrates (Pastorova et al. 1994; Almendros et al. 1989b). The major thermal rearrange- ment products of most carbohydrates are anhydrosugars (Figure 5) such as levoglucosenone, but total assemblages of pyrolytic products may amount to hundreds of major compounds including furans, acetic acid and homologous series of alkylbenzenes, tetralins, indenes, as well as a conspicuous series of polycyclic aromatic hydrocarbons, with their relative abundance dependant on the intensity of heating (Almendros et al. 1997).

5. Fire-induced formation of recalcitrant aliphatic and aromatic macromolecules via condensation of biogenic organic matter compounds

Most products from the thermal cleavage of SOM are both reactive and polyfunctional, i.e., compounds prone to spontaneous condensation and polymerization into three-dimensional structures. They show some resemblance to humic substances, although frequently have comparatively low proportions of reactive oxygen-containing functional groups. As regards the stabilization of $\mathrm{C}$-forms in soil, all of the above processes are likely to be relevant. The chaotic structure of humic substances and the newly-formed $\mathrm{C}-\mathrm{C}$ bonds (intra-macromolecular bridging) enhanced by the fire, give the SOM a

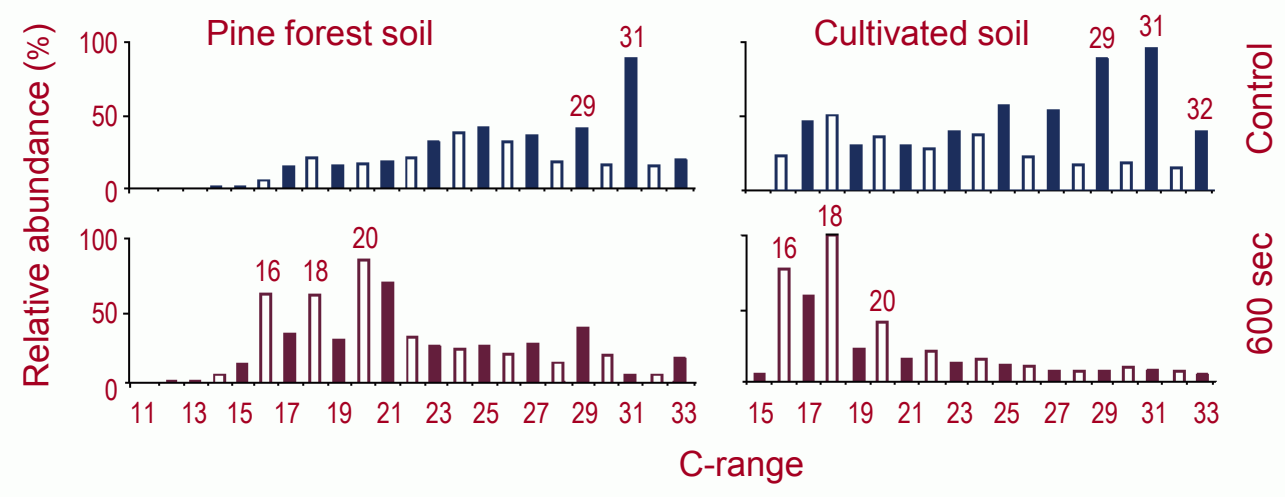

Figure 4. Changes in n-alkane patterns of control soils (above) and soils heated at $350^{\circ} \mathrm{C}$ for 600 seconds. Open and solid bars differentiate between odd- and even- $C$ numbered alkanes, respectively. 


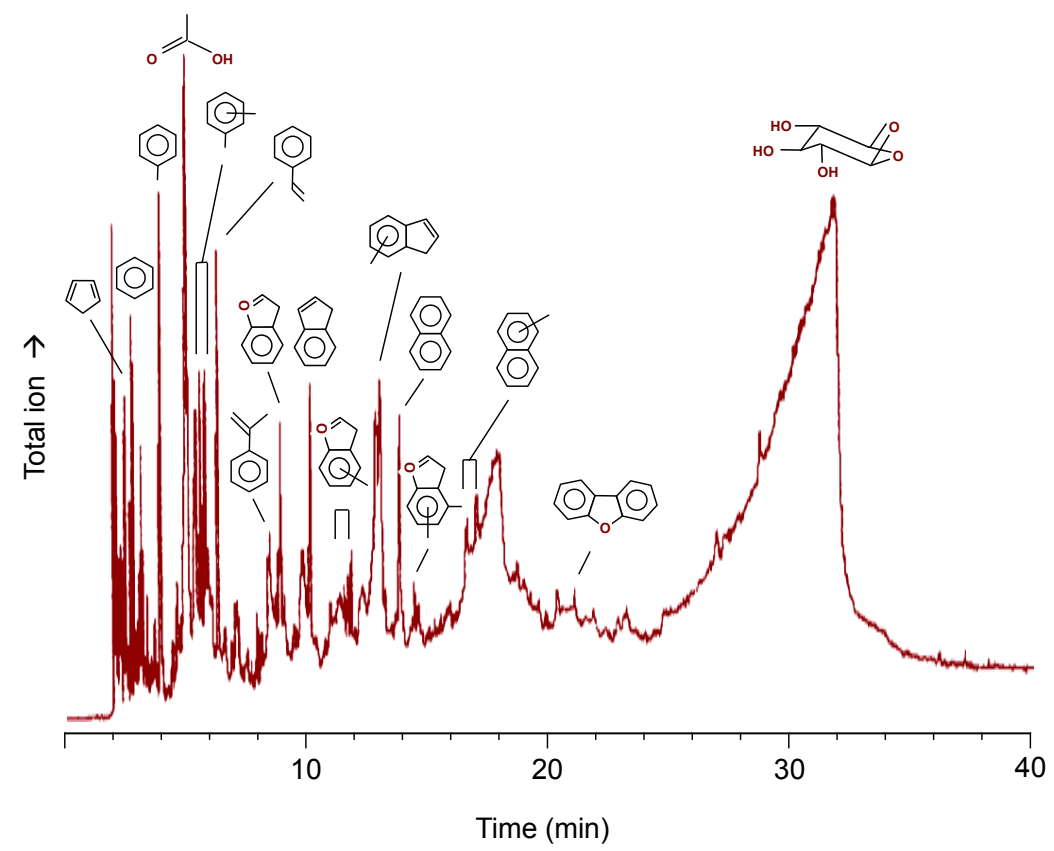

Figure 5. Pyrolysis products from a heated cellulose preparation: heating time for $180 \mathrm{sec}$ at $350^{\circ} \mathrm{C}$. The structures of the major compounds are shown on the peaks.

generalized recalcitrance against chemical and biological degradation (Almendros and Dorado 1999; Knicker et al. 2011). This lack of repeating structures is characteristic of recalcitrant natural organic matter. The increased resistance to biodegradability is combined with an effective negative short-term effect of fire on the microbial activity (Barreiro et al. 2010).

After the development of ${ }^{13} \mathrm{C}$ NMR spectroscopy under reliable quantitative conditions, a series of studies were carried out in order to examine the dynamic balance between the different C-types involved in the fire-induced reactions (Knicker at al. 2006b). This represents an interesting progress, since chemical and pyrolytical approaches in general lead to non-stoichiometric yields of degradation units that are only valid for comparative purposes in a series of samples subjected to the same treatments. Calculations based on percentages of $C$ in humic samples subjected to laboratory heatings under con- trolled conditions were suitable for monitoring the weight loss, the initial and final $\mathrm{C}$ percentages and the C-lost as $\mathrm{CO}_{2}$ (Figure 6). With these data, and the integration values of the different ${ }^{13} \mathrm{C}$ NMR signals (Almendros et al. 1990, 1992), the calculated values supported the hypothesis that after moderate heating (up to 60 seconds at $350{ }^{\circ} \mathrm{C}$ ) the increase in aromaticity of the SOM corresponds mainly to the concentration of resistant aromatic compounds concomitant of the selective depletion of aliphatic structures. Nevertheless, after severe heating representative of higher intensity wildfires (i.e., weight loss greater than $40 \%$ ) there was an absolute increase in the amount of aromatic $\mathrm{C}$ compared to unburnt samples. The quantitative values also suggest that carbohydrates or carbohydrate-derived structures such as furans and cyclic ketones are probably the main source of these secondary aromatic compounds generated by severe heating. Concerning the remaining aliphatic products i.e., alkyl carbons, diverse transformations were 


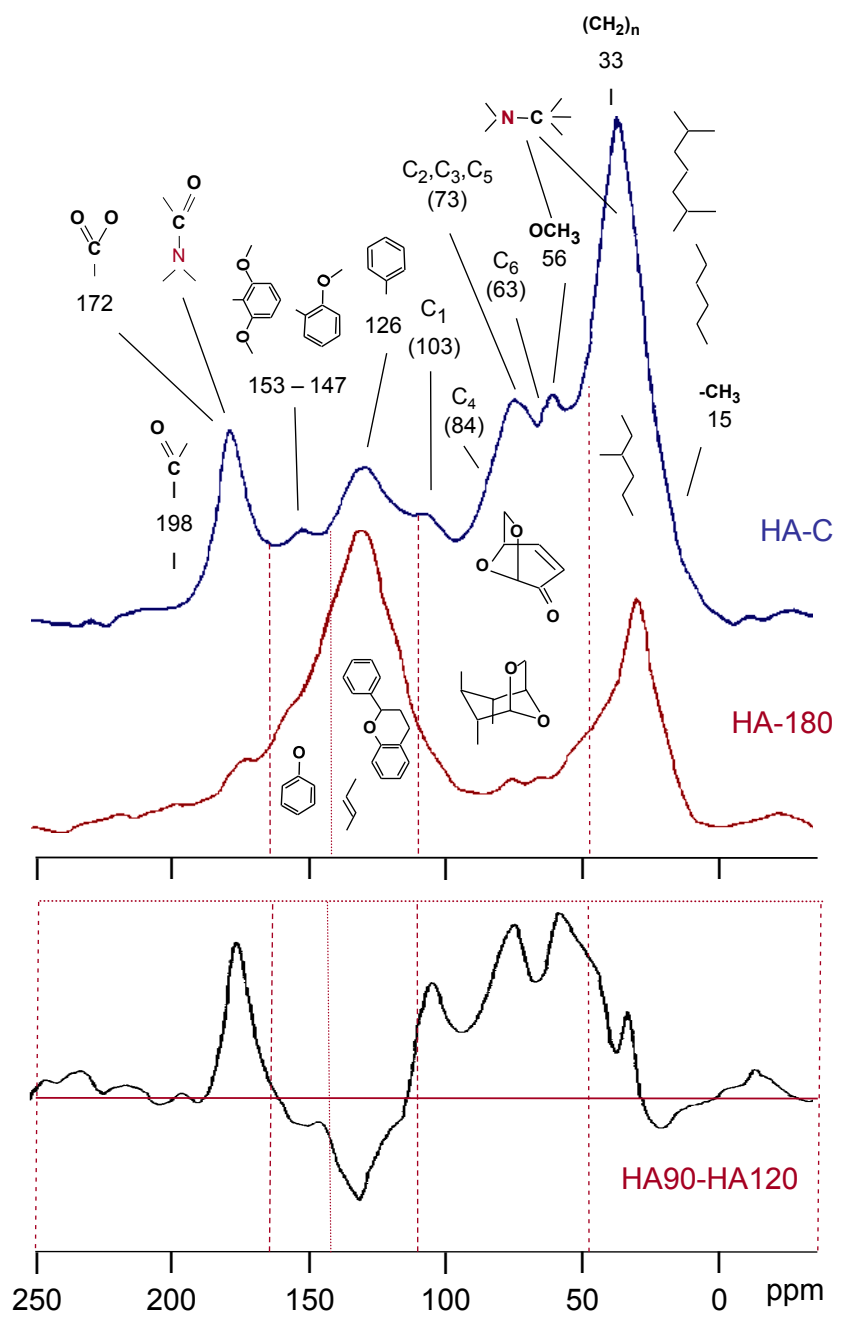

Figure 6. Fire-induced changes in humic acid reflected by solid-state nuclear magnetic resonance spectroscopy.

HAB: control humic acid from unburnt sample; HA-180: after heating for 180 seconds at $350^{\circ} \mathrm{C}$.

HA90-HA120: example of quantitative difference spectrum obtained by digital subtraction of two HA spectra at different stages of progressive heating. Spectra were previously scaled considering the C-loss between the two heating stages. The negative peak ca. $126 \mathrm{ppm}$ indicates the aromatic, unsaturated material formed during heating that was not present in the unburnt sample. Positive peaks correspond to structures selectively removed from HA as a result of heating.

Spectral ranges and main peaks: $0-46 \mathrm{ppm}=\mathrm{alkyl}+\alpha-a \operatorname{mino}(13=$ methyl, $21=$ acetate, $33=$ polymethylene); $46-110 \mathrm{ppm}=0$-alkyl $(56=$ methoxyl $+\alpha$-amino $)$ numbers in brackets refer to $\mathrm{C}$-types in glucopyranosyde-derived structures; $103-105=$ anomeric $C$ in carbohydrate, quaternary aromatic carbons in tannins); $110-160 \mathrm{ppm}=$ aromatic/unsaturated $(126=$ unsubstituted, $147-153=$ heterosubstituted, vanillyl+syringil lignin units); $160-200$ ppm=carbonyl $(172=$ carboxyl + amide, 198= ketone/aldehyde). 
observed. These consisted of thermoevaporation, cracking and 'fixation' probably by molecular entrapment into condensed $\mathrm{C}-\mathrm{C}$ bonded structures in humic substances, or even chemical condensation and polymerization in the case of unsaturated structures (Almendros et al. 1996, 2005). These ${ }^{13} \mathrm{C}$ NMR quantitative studies showed that a recalcitrant domain of alkyl Cs, probably including resistant $\mathrm{N}$-compounds, is systematically present in natural and laboratory-heated humic samples. To date, no detailed information has been presented on the chemical structure of this recalcitrant aliphatic domain shown by ${ }^{13} \mathrm{C}$ and ${ }^{15} \mathrm{~N}$ NMR spectroscopy of SOM affected by fires. It has some similarity to a 'protokerogen-like' material showing a typical 'bimodal' ${ }^{13} \mathrm{C}$ NMR spectroscopic profile (Figure 6) indicating a residual $\mathrm{C}=\mathrm{O}$ signal ca. $172 \mathrm{ppm}$ (residual carboxyl, ester/lactone and amide Cs), a dominant aromatic region (160-110 ppm), and a significant $(>30 \%)$ signal for alkyl structures peaking at $33 \mathrm{ppm}$, suggesting a polymethylene or cycloalkane structure. These are compatible with alkyl side-chains in a melanoidin (aminoacid and carbohydrate-derived) domain resistant to chemical and biological degradation.

6 Thermal formation of heavily condensed, defunctionalized, black-carbon type aromatic structures in soil organic matter

Not only in-depth structural characterization of the black-carbon residues but also its quantitative determination is especially difficult and probably biased (Skjemstad et al. 1999; Preston and Schmidt 2006; Reeves et al. 2008), owing to its multiple-ring polycyclic skeletal structures which tend to remain 'invisible' after ${ }^{13} \mathrm{C}$ NMR spectroscopy due to intrinsic problems with the $\mathrm{T} 1$ relaxation time in polycondensed aromatic structures (Knicker et al. 2004).

Complementary studies based on chemical degradation also provide limited additional information because black carbon structures in general do not readily release structural blocks upon chemolysis, but are degraded into $\mathrm{CO}_{2}$ and $\mathrm{H}_{2} \mathrm{O}$ under the effect of the strong chemical reagents. This is hypothetically due to its structure, consisting of a continuous condensed network where the strength of the bonds between atoms is similar to that between possible discrete molecular units (Almendros et al. 2004; González-Vila et al. 2002; González-Pérez et al. 2002). Dipolar dephasing ${ }^{13} \mathrm{C}$ NMR suggests a polycondensed three-dimensional structure with small clusters of about six aromatic rings connected by approximately two bridging Cs (Knicker et al. 2005a). Alternatively, benzanthracene-like structures joined together with three to five bridging $\mathrm{Cs}$ are possible (Knicker et al. 2005a, 2005b).

7. The fate of nitrogen compounds in fire-affected soil organic matter

Fire-induced changes are especially relevant to the total concentration, chemical structure, and potential bioavailability of $\mathrm{N}$-forms, and consequently the effect on the dynamics of the whole $\mathrm{N}$ - and $\mathrm{C}$-cycles. It seems probable that fires play an outstanding role in the long-term stabilization of $\mathrm{N}$-compounds into complex recalcitrant, insoluble macromolecular material (González-Vila et al. 2002). Early studies based on ${ }^{15} \mathrm{~N}$ NMR under quantitative acquisition conditions (Almendros et al. 1991a) suggested that most of the nonhydrolyzable- $\mathrm{N}$ in soils does not consist of heterocyclic $\mathrm{N}$-compounds, as was hypothesized in the classical literature based on $20-60 \%$ 'unknown $\mathrm{N}$ ' in SOM being resistant to hydrolysis. Extensive composting of ${ }^{15} \mathrm{~N}-\mathrm{la}$ belled fresh plant residues or ${ }^{15} \mathrm{~N}$ NMR analysis of biologically active soils failed to demonstrate the major accumulation of $\mathrm{N}$-forms other than those present in proteins, chitins or aminoacids (Knicker et al. 1996 and references therein). More recent laboratory heating studies on, for example, ${ }^{15} \mathrm{~N}$ enriched plant-biomass, indicated that fire is necessary to produce heterocyclic $\mathrm{N}$-compounds (Figure 7) in concentrations detectable by ${ }^{15} \mathrm{~N}$ NMR (Almendros et al. 2003b; González-Vila et al. 2006a). This phenomenon could explain the frequent decrease of the $\mathrm{C} / \mathrm{N}$ ratio observed in most post-fire soils (Figure 2). Although the exact structure and reasons for the low hydrolyzability of the fire-resistant amide $\mathrm{N}$-forms in SOM remain obscure (Knicker et al. 1996), it seems clear that fires produce specific qualitative changes not achieved by biological transformations of plant and microbial biomass. 


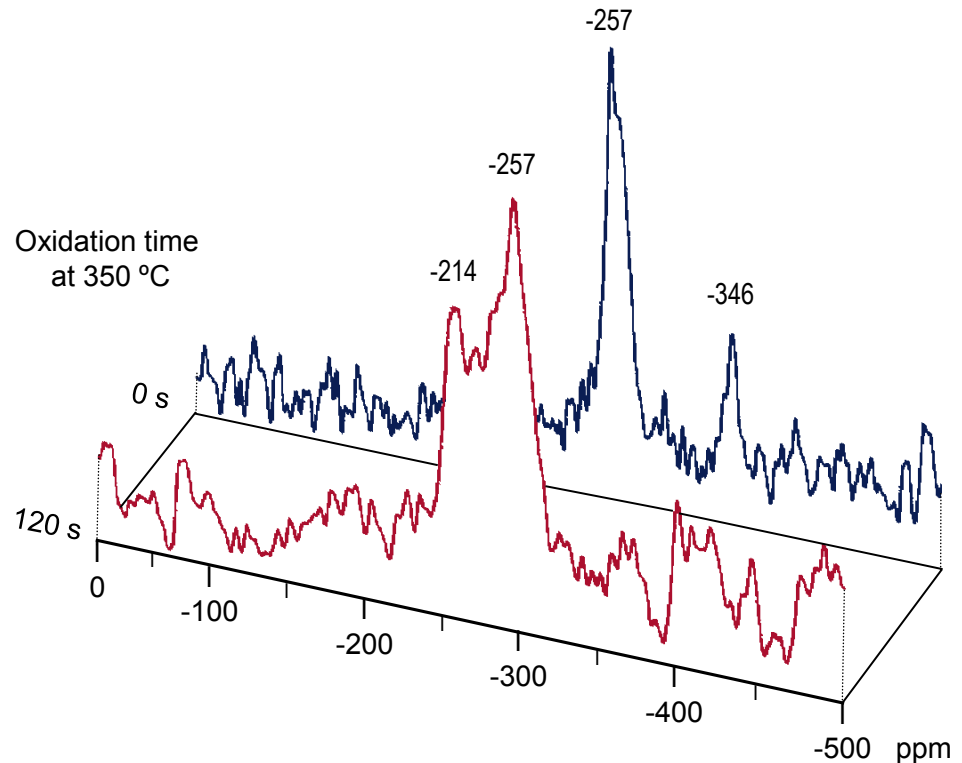

Figure 7. Solid-state CPMAS ${ }^{15} \mathrm{~N}-\mathrm{NMR}$ spectra of peat samples subjected to progressive thermal oxidation at $350{ }^{\circ} \mathrm{C}$ for different periods up to $150 \mathrm{~s}$. The chemical shift scale is normalised to nitromethane $(0 \mathrm{ppm})$.

Additional insights on the nature of soil organic $\mathrm{N}$-forms and the effect of fire can be obtained using destructive techniques, mainly analytical pyrolysis, which is suitable for structural research on condensed $\mathrm{C}-\mathrm{C}$ linked macromolecular material such as charred organic matter (González-Vila et al. 2001; González-Pérez et al. 2004). In the case of lignocellulosic biomass, a progressive increase in imidazole-releasing SOM structures was found, whereas structures yielding pyrroles and pyrrolynes were rapidly depleted. Indole-releasing structures showed an intermediate thermal stability. In these studies using progressively heated plant biomass, it is also important to point out that cyclization of organic $\mathrm{N}$-forms paralleled the accumulation of polyalkyl resistant material, which probably consists of chemically-bonded alicyclic or polymethylene compounds in addition to structural domains yielding non-volatile alkanes (e.g., $>\mathrm{C}_{30}$ ). This recalcitrant polyalkyl material could consist of pre-existent plant or microbial lipids, which could concentrate by heat-induced molecular entrapment into condensed three-dimensional black-carbon intergrades, or derive from cracking and re-condensation reactions of long-chain polymethylene wax constituents including lipid polymers. The release of additional amounts of waxes from rye-grass biomass heated for 90 $\mathrm{sec}$ at $350^{\circ} \mathrm{C}$ supports the suggestion that biogenic polyalkyl compounds can stabilize in the charred residuals when the carbohydrate has been completely transformed by the effect of fire (González-Vila et al. 2001).

8. Molecular proxies of the impact of fire in the molecular signature of soil organic matter

Due to the complex simultaneous reactions occurring during forest fires, where the cleavage of macromolecules is simultaneous with the condensation of new $\mathrm{C}-\mathrm{C}$ linked structures probably initiated by free-radical reactions, the study of fire dynamics is practically focused on the analysis of 'snapshots' at selected stages of transformation (Almendros et al. 2003b). Within these limitations, most of the studies on the changes in the $\mathrm{C}$-and $\mathrm{N}$-forms have been 
restricted to establishing valid proxies of the impact of fires in SOM (González-Vila et al. 2006b; Piedra-Buena et al. 2009a, 2009b). These fireimpact surrogates could be useful in assessing damage levels, as well as providing evidence of the impact of fire in the past, and explaining peculiar features in 'highly-matured' humic substances (Hernández and Almendros 2012).

From this point of view, changes in the $\mathrm{N}$-containing structures have a greater diagnostic value than the changes in the $\mathrm{C}$-backbone of the SOM. This criterion arises from the fact that most of the post-fire humic substances show features that are also typical of the advanced stages of diagenetic alteration and microbial reworking in fire-unaffected ecosystems.

Monitoring the changes in $\mathrm{N}$-containing SOM structures is probably the most promising source of analytical proxies of the impact of fire. However, investigations aiming to isolate or concentrate heterocyclic $\mathrm{N}$-containing structures in SOM by means of physical and chemical laboratory treatments have had little success in obtaining heterocyclic $\mathrm{N}$-structures in amounts suitable for analysis by ${ }^{15} \mathrm{~N}$ NMR. Nevertheless, in samples subjected to severe heating (e.g. after $150 \mathrm{sec}$ at $350^{\circ} \mathrm{C}$ ) the amount of newly-formed heterocyclic N-compounds (Figure 7) may dominate the concentration of peptide structures (Almendros et al. 2008), although laboratory heating experiments have demonstrated that not all peptidestructures of the biomass are transformed by fire, and substantial amounts of amide- $\mathrm{N}$ may remain even when total weight loss of heated samples reaches ca. $30 \%$. Some portion of these resistant amides forms could consist of melanoidins (or Maillard-like products), typically arising from thermal treatment of mixtures containing sugars and aminoacids. The fact that before thermal treatment, the concentration of pyrrole-type $\mathrm{N}$-forms in SOM biomass lay under the detection limits of ${ }^{15} \mathrm{~N}$ NMR spectroscopy clearly supports their pyrogenic origin (Knicker et al. 2010).

Complementary research on the changes to the pyrolytic assemblages of SOM in organic soils (sapric peat) after progressive heating (Piedra-
Buena et al. 2009a, 2009b, 2010; Kiersch et al. 2012) has also been successful in showing that $\mathrm{N}$-structures that did not exist in unheated samples, formed after fire. When the experiment is carried out with sufficient a number of intermediate stages, it is also possible to observe the evolution of the Shannon's diversity index for all families of pyrolysis compounds (including lignin-derived methoxyphenols, alkanes, alkenes, and $\mathrm{N}$-compounds). The number and concentration of $\mathrm{N}$-compounds show significant increases after the thermal impact, mainly at the stages in which heterocyclic compounds are newlyformed (up to $120 \mathrm{sec}$ at $350^{\circ} \mathrm{C}$ ). After this initial increase in molecular diversity, the assemblages of $\mathrm{N}$-compounds are progressively simplified with the progress of heating, with a drastic reduction in the amounts of compounds prevailing at previous stages, mainly pyrazine, methylpyrroline and pyrrole.

This is also the case with the increase in aromaticity, the depletion of aliphatic structures and the loss of hydrophilic properties, typically reflected by increased optical density of the humic acids and the changes in its $\mathrm{H} / \mathrm{C}$ and $\mathrm{O} / \mathrm{C}$ atomic ratios (Tinoco et al. 2006; Shindo et al. 2003). Additional descriptors that betray the influence of fire on SOM have been postulated after the use of multianalytical approaches, such as the systematic increase in benzenecarboxylic acids (Figure 8) after alkaline degradation of the humic acids (Almendros et al. 1990; Glaser et al. 1998), or the increased yields after analytical pyrolysis of polycyclic aromatic structures (naphthalenes, phenanthrenes, etc.). The decreased intensity in post-fire samples of typical dihydroxyperylenequinone units frequent in most humic acids and ascribed to the metabolism of some pigmented deuteromycetes (Kumada and Hurst 1967), suggest the instability of quinone chromophors against thermal impact.

Concerning the biological properties of the SOM, laboratory incubation of fire-affected and unaffected soil samples confirm the comparatively low biodegradability (decreased mineralization coefficient and total $\mathrm{CO}_{2}$ release) of the post-fire soils despite the frequent increase in its $\mathrm{pH}$ and concentrations of bioavailable cations 

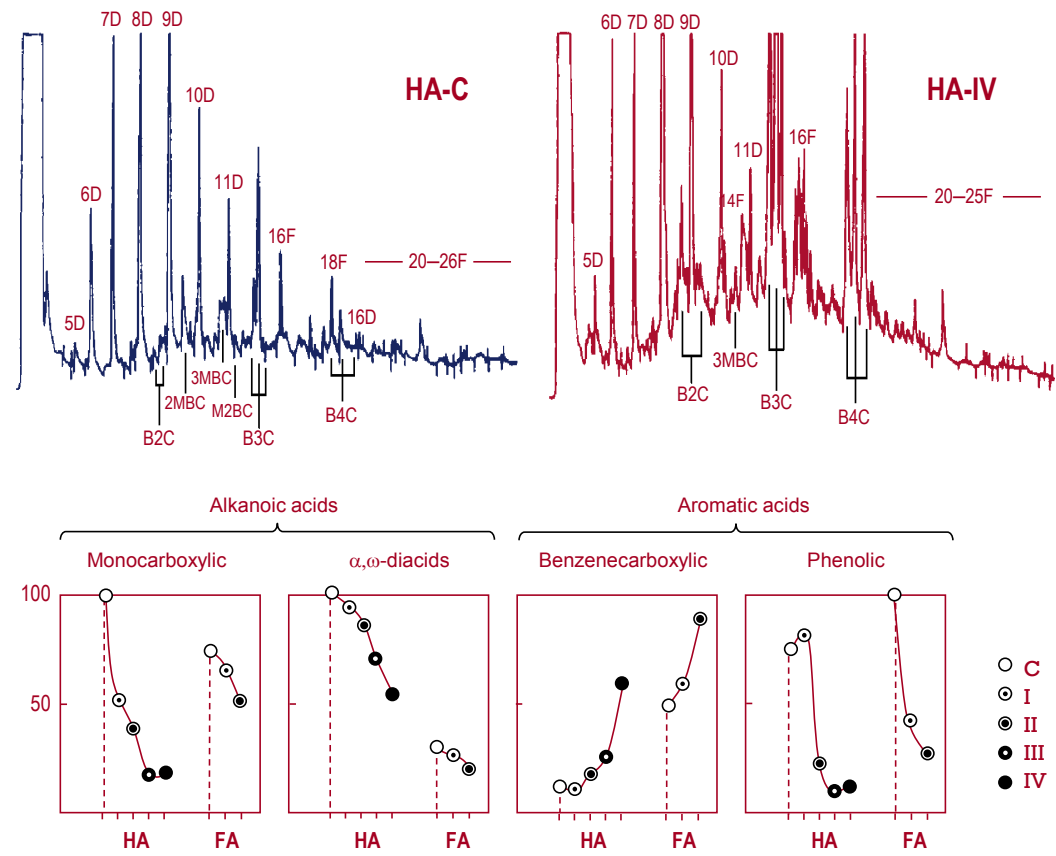

Aromatic acids

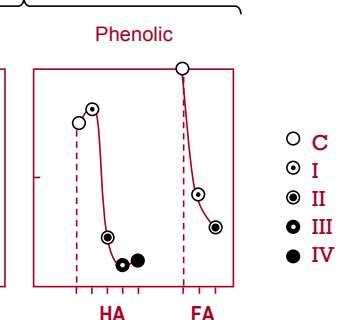

Figure 8. Fire-induced changes in the relative amounts of degradation products obtained after alkaline permanganate oxidation of humic acid: HA-C humic acid from the control soil, HA=IV after 150 seconds of heating at $350^{\circ} \mathrm{C}$. The line plot shows changes in the relative abundances of the main families of permanganate degradation products from humic acids (HA) and fulvic acids (FA) subjected to progressive heating: Labels on the peaks indicate the main families of compounds and $C$ range numbers: $F=$ fatty acid methyl ester, $D=\alpha, \omega$-alkanedioic acid methyl ester, $\mathrm{BnC}=$ benzene- $n$-carboxylic acid $n$-methyl ester, $\mathrm{M}=$ methoxy.

(Almendros et al. 1984a, 1984b; Hernández et al. 1997; Tinoco et al. 2006; Marcos et al. 2007).

9. The debatable long-term recalcitrance of pyrogenic organic matter

Both the analysis of fire-affected natural organic matter as well as simulation experiments suggest a continuum of black carbon intergrades where only a limited portion should really be considered as a C-C-linked three-dimensional polyaromatic network with some domains of multilayer of graphite-like structures (González-Vila et al. 2009). In fact, most fire-affected organic matter still includes a heterogeneous mixture of thermally altered biomacromolecules (Knicker et al. 2007).
Laboratory analyses based on chemical degradations and ${ }^{13} \mathrm{C}$ NMR of plant chars showed the presence of discrete proportions of the original lignin backbone, associated with furans and anhydrosugars, suggesting residual or diagenetically-altered hemicelluloses and celluloses. In general chars also include substantial content of N-heteroaromatic carbon structures mainly derived from peptides (Knicker et al. 2003a, $2003 \mathrm{~b})$, as well as condensed structures with frequent O- and S-substitutions (Knicker at al. 2006c).

According to this conception, most of the char would be perfectly amenable to biological and chemical oxidation, compatible with the concentration in soil of a minor recalcitrant blackcarbon fraction (material with more than $90 \%$ C) 
which would represent subfossil organic matter from the viewpoint that its $C$ is not readily interchanged with that in the atmosphere. This heavily condensed, high C-range black carbon could represent the characteristic C-form in some black-colored soils (Ponomarenko and Anderson 2001). This is supported by laboratory experiments on extreme reference materials such as activated charcoal with negligible amounts of $\mathrm{O}, \mathrm{H}$ and $\mathrm{N}$ (unpublished results), where weight losses and yields of oxidative degradation products other than $\mathrm{CO}_{2}$ and $\mathrm{H}_{2} \mathrm{O}$ are little significant even under $\mathrm{pH}$, temperature and pressure conditions not existing in environmental conditions.

Reduced biodegradation rates in post fire-soils have been justified by invoking the argument that high fire intensity creates recalcitrant materials (Hatten and Zabowski 2010), and which are in line with studies suggesting that black C-type SOM could represent a significant sink of atmospheric $\mathrm{CO}_{2}$ (Kuhlbusch and Crutzen 1995). Other studies (Hockaday et al. 2006) supplied experimental data that was interpreted to show that pyrogenic $\mathrm{C}$-forms were more biodegradable than previously believed. However, the divergent experimental results reported by different authors (Steiner et al. 2007) are based on substantially different pyrogenic materials. In any case, it seems clear that in soils subjected to repeated burnings, substantial amounts of the pre-existent black carbon are destroyed in the successive fire events (Dai et al. 2005; Rovira et al. 2009).

10. Changes to surface properties of soil organic matter resulting in water repellency

Although significant enhancement in soil water repellency is a classic result of wildfires and controlled heatings (e.g. Viro 1974; Doerr et al. 2000; Mataix-Solera et al. 2012), no exhaustive studies have been done on the factors involved in this soil property, their effect on SOM biodegradability, and its bearing on the C-cycle.

The role of soil hydrophobic substances and its speciation status (its occurrence as free extractable compounds, or bonded to organic matter in the surfaces or the inner voids of aggregates) was typically considered to be of prime importance in the water repellency (De Blas et al. 2010), which in extreme cases takes several minutes to be estimated with the classical WDPT (water drop penetration time) test.

Molecular characterization of the SOM in waterrepellent soils suggested interactions between fire-induced intrinsic and extrinsic effects. For instance, thermal distillation of lipid fractions in the course of fires and its further translocation and fixation of soil organic and mineral surfaces was considered by many authors to produce hydrophobicity (Savage et al. 1972; Savage 1974; DeBano et al. 1970). Comparison of samples from the same soil after wildfire and laboratory heating indicated that water repellency increases in both cases. The amount of free lipids increased after natural fires due to probable external inputs from epicuticular waxes and resins, but decreased progressively in the laboratory closed system (Almendros et al. 1988). This suggested that changes in surface properties of the post-fire SOM (mainly the removal of carboxyl, phenolic and alcoholic hydrophilic functional groups) and further changes in the colloidal properties (mainly condensation of fulvic acid-type fractions) enhanced by intramolecular bridging in humic acids and humin, may play a substantial synergistic role in changing organic matter to heavily hydrophobic (Almendros et al. 2010b). Additional enhancement in water repellency is probably due to surface exposition of polymethylene constituents, or even polycyclic aromatics in the case of heavily condensed black carbon intergrades.

Further studies on extremely hydrophobic soils revealed inter-related factors involved in soil water repellency, in particular suggesting that lipid compounds should not necessarily be the key agents. The early fire-induced transformation in macromolecular SOM, with drastic dehydration and decarboxylation reactions, should not be neglected during the interpretation of the origin of hydrophobicity in fire-affected soils.

In the case of extremely water-repellent soils, the removal of free hydrophobic compounds (solvent extraction) only leads to some decrease 
in water repellency. Further removal of particulate organic fractions (free organic matter) in addition to the successive extraction of humic and fulvic acids (with the concomitant effect of the polar extractants used in cleaving polyvalent cation bridges) was required for a total disappearance of the hydrophobicity (De Blas et al. 2010).

Molecular characterisation of the lipid compounds sequentially removed from the soil after these chemical treatments removing organomineral cements in soil aggregates, suggests that the total amount and the molecular composition of soil lipids, by itself, only explains a small portion of the severe water repellency (Almendros et al. 2012). Apart from this, in the soils studied (pine and eucalypt forests) the lipid molecules more related with the repellency were characteristic compounds synthesized by higher plants, not by microorganisms, i.e., mono- and sesquiterpenes and oxygenated terpenes, as well as long-chain $\left(>C_{20}\right.$ ) alkanes (De Blas et al. 2011, 2012).

To large extent, water repellency in these forest soils would be explained by changes in the properties of the soil matrix, i.e., the removal or occlusion of free oxygen-containing groups and the association of non-extractable alkyl constituentsmainly alkanes-onto humic acids. According to this conception, water repellency would be an emergent soil property not primarily dependant on hydrophobic coatings at microaggregate levels, but dependant instead on hydrophobic cements tightly fixed in the stable humus-clay matrix (De Blas et al. 2012). In the case of fire-affected soils, this would depend on the fires' intensity and duration, and has been shown to have a significant effect on other soil physical properties important to soil health such as aggregate stability. Although high-intensity fires may lead to a severe decrease in organic matter associated with the loss of structural stability, in some cases an increase has been reported and attributed to increased water repellency (Mataix-Solera et al. 2011).
7. Final considerations on hypothetical effects of fire on the soil C-sequestration, its effects on the humification pathways and the fate of pyrogenic organic matter

The complex dynamics induced by fire in the accumulation mechanisms of soil organic $C$ is hypothesized in Figure 9. The scheme differentiates between mechanisms in which the originally biodegradable SOM becomes stabilized in soil for extended periods (selective preservation, 'inherited organic matter'...) and specific processes of formation of humic-like substances including newly-formed soil C-forms in soil (Almendros 2008a). Depending on the intensity of the mechanisms involved, fire effects may result in changes in SOM functional groups leading either to hydrophobicity or water repellency processes, but may also increase the stability of the links between SOM and minerals through the formation of e.g., irreversible $\mathrm{H}$-bridges which remain after rewetting the soil. As stated before, intense fires may also determine the formation of new cyclic or condensed organic components, and the polymerization of soluble precursors. In general, fire causes structural changes of biomacromolecules (cellulose, lignin, etc.) causing their structures to be less biodegradable and not easily recognizable by specific soil enzymes. There are also very stable SOM forms which are rapidly generated by the effect of the fire, e.g., pseudomelanoidins from thermal dehydration of carbohydrates (charred material), or Maillard products (melanoidins), from nitrogen compounds and carbohydrates. Some recent studies have shown even the accumulation of stable aliphatic $\mathrm{C}$-forms from the condensation of lipid compounds (mainly unsaturated), which turn into resins or become attached to pre-existing humic substances in soil (Almendros et al. 1991b). Finally, severe heating leads to the accumulation of a continuum of charcoal intergrades from lignocellulosic biomass generically referred to as 'black carbon'.

From the experimental viewpoint, it is extremely difficult to observe any microbial assimilation of charcoal, either because it did not occur, or because the methods frequently used were 


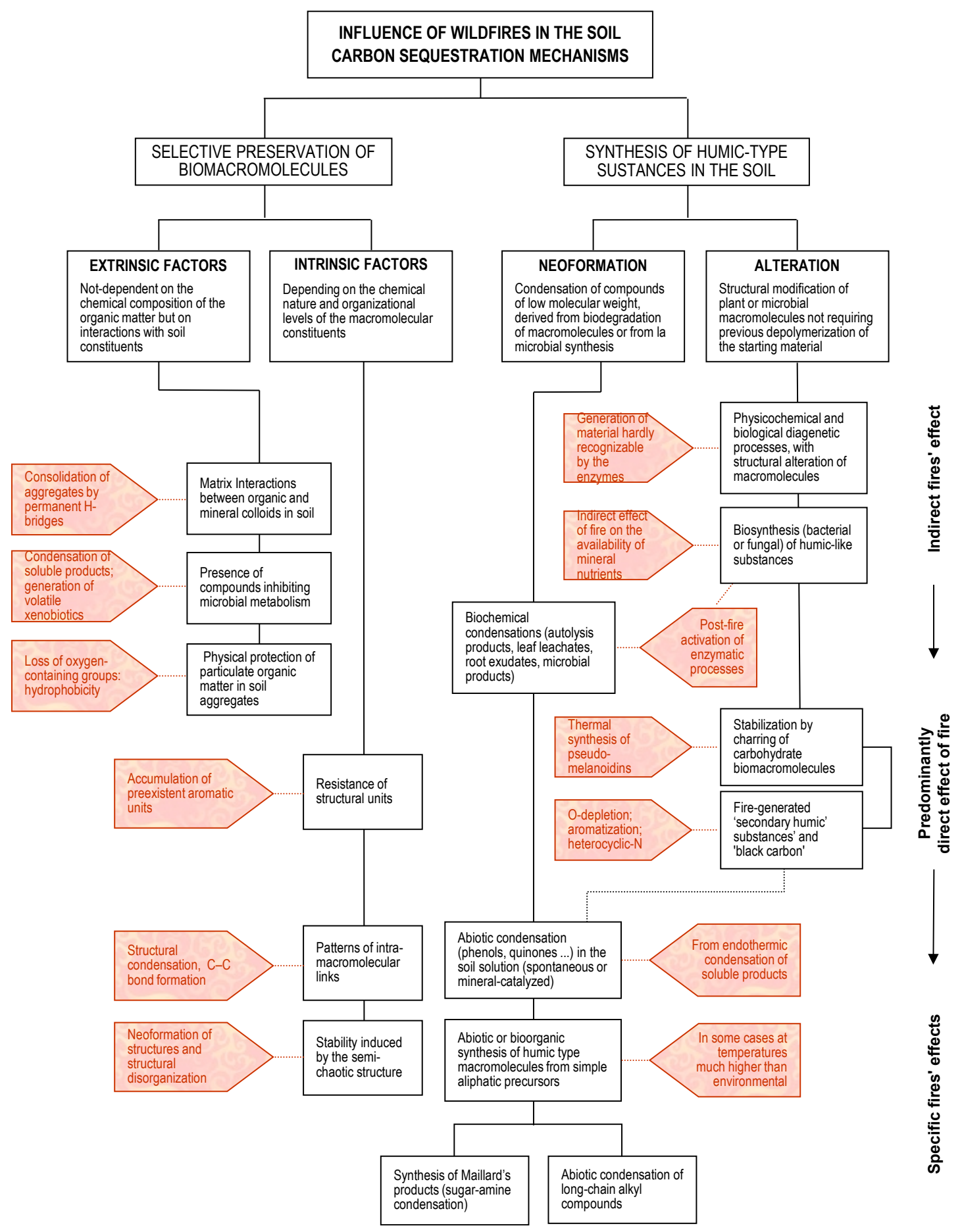

Figure 9. Analysis of the effect of fire (pentagonal boxes) on the soil carbon cycle, showing its effect on the various mechanisms responsible for the formation of humic substances and $\mathrm{C}$ sequestration (rectangular boxes). 
not sufficiently sensitive (Bruun et al. 2008). Although black carbon has been considered to be biodegradable in a reasonable period of time in tropical conditions (Poirier et al. 2002) mainly when finely divided, it is in general considered highly recalcitrant. Black carbon may represent a significant proportion of soil $\mathrm{C}$ in some gray soils, but is very difficult to quantify by conventional spectroscopic or wet analytical techniques. In any case, the secondary transformation of this recalcitrant $\mathrm{C}$-form into humic-type substances should not be neglected: Laird et al. (2008) considered black carbon particles aged in soil to be oxidized, incorporating carboxylic groups as well as a series of aliphatic compounds, either by adsorption of dissolved biogenic compounds from the soil solution, or by direct deposition of microbial materials from microbes. At this point, some authors have suggested that abiotic processes were more important for oxidation of black carbon than the biotic processes, at least during short-term (4-month) incubations (Cheng et al. 2006).

Oxidation of black carbon in soil results in the export of a wide variety of polycyclic aromatic compounds to the dissolved organic matter pool (Hockaday et al. 2006). Nevertheless, since black carbon may frequently occur as an extremely fine, particulate soil fraction, it is probable that its progressive depletion from soil surface horizons is to large extent due to horizontal and vertical migration (Guggenberger et al. 2008; Rumpel et al. 2009) rather than to chemical or biological in situ transformations.

Finally, analyzing the current state of the knowledge about the impact of fire in the SOM in recent literature, the topics of recurring interest to research workers in many countries have been the unraveling of the complex molecular structure of pyrogenic SOM forms (by using non-destructive spectroscopies, specific wet chemical degradation, chemotaxonomic and metabolomic approaches, etc.), and the discrimination of the selective effects of fire from the biogeochemical pathways which contribute to the natural stabilization of $C$ forms in soil.

\section{Acknowledgements}

The authors wish to acknowledge two anonymous referees for their fruitful comments on the submitted paper and to financial support by the Spanish CICyT under grant CGL2008-04296. 


\section{REFERENCES}

- Aiken GR, McKnight DM, Wershaw RL, MacCarthy P. 1985. Humic substances in soil, sediment and water: geochemistry, isolation, and characterization. New York: John Wiley. 692 pp.

- Almendros G, Polo A, Ibáñez J, Lobo MC. 1984a. Contribución al estudio de la influencia de los incendios forestales en las características de la materia orgánica del suelo. I: Transformaciones del humus en un bosque de Pinus pinea del Centro de España. Rev Ecol Biol Sol. 21(1):7-20.

- Almendros G, Polo A, Lobo MC, Ibáñez J. 1984b. Contribución al estudio de la influencia de los incendios forestales en las características de la materia orgánica del suelo. II: Transformaciones del humus por ignición en condiciones controladas de laboratorio. Rev Ecol Biol Sol. 21(2):145-160.

- Almendros G, Martín F, González-Vila FJ. 1985. Efecto de los incendios forestales sobre los constituyentes orgánicos del suelo. Seminario sobre Bases Ecológicas de la Gestión del Medio Terrestre; 1985 Dec; Diputación de Barcelona. Servicio de Parques Naturales; p. 98-99.

- Almendros G, Martín F, González-Vila FJ. 1988. Effects of fire on humic and lipid fractions in a Dystric Xerochrept in Spain. Geoderma 42:115-127.

- Almendros G, González-Vila FJ, Martín F. 1989a. Alteraciones del humus en bosques mediterráneos continentales afectados por incendios. In: Proc. II. Jornadas Sobre Bases Ecológicas para la Gestión Ambiental; Zaragoza: C.I.E.H.A.M.-I.A.M.Z; Options Méditérranéennes. Ser Séminaires 3:95-99.

- Almendros G, Sanz J, Sobrados I. 1989b. Characterization of synthetic carbohydrate-derived humic-like polymers. Sci Total Environ. 81/82:91-98.

- Almendros G, González-Vila FJ, Martín F. 1990. Fireinduced transformation of soil organic matter from an oak forest. An experimental approach to the effects of fire on humic substances. Soil Sci. 149(3):158-168.

- Almendros G, Fründ R, González-Vila FJ, Haider KM, Knicker H, Lüdemann H-D. 1991a. Analysis of ${ }^{13} \mathrm{C}$ and ${ }^{15} \mathrm{~N}$ CPMAS NMR-spectra of soil organic matter and composts. FEBS Lett. 282:119-121.

- Almendros G, Sanz J, González-Vila FJ, Martín F. 1991b. Evidence for a polyalkyl nature of soil humin. Naturwissenschaften 78:359-362.

- Almendros G, González-Vila FJ, Martín F, Fründ R, Lüdemann H-D. 1992. Solid state NMR studies of fireinduced changes in the structure of humic substances. Sci Total Environ. 117/118:63-74.
- Almendros G, Guadalix ME, González-Vila FJ, Martín F. 1996. Preservation of aliphatic macromolecules in soil humins. Org Geochem. 24(6/7):651-659.

- Almendros G, Dorado J, González-Vila FJ, Martín F. 1997. Pyrolysis of carbohydrate-derived macromolecules: its potential in monitoring the carbohydrate signature of geopolymers. J Anal Appl Pyrolysis 40-41:599610.

- Almendros G, Dorado J. 1999. Molecular characteristics related to the biodegradability of humic acid preparations. Eur J Soil Sci. 50:227-236.

- Almendros G, Kgathi D, Sekhwela M, Zancada MC, Tinoco P, Pardo MT. 2003a. Biogeochemical assessment of resilient humus formations from virgin and cultivated northern Botswana soils. J Agric Food Chem. 51:4321 4330 .

- Almendros G, Knicker H, González-Vila FJ. 2003b. Rearrangement of carbon and nitrogen forms in peat after progressive thermal oxidation as determined by solid-state ${ }^{13} \mathrm{C}$ - and ${ }^{15} \mathrm{~N}$ spectroscopy. Org. Geochem. 34:1559-1568.

- Almendros G, González Vila F, D’Acqui LP, Ristori G, Zancada MC, Pardo MT. 2004. Stability against pyrolytic cleavage and the occurrence of extremely recalcitrant humic matter in Southern African Soils. In: Martin-Neto L, Bastos Pereira Milori DM, Lopes da Silva WT, editors. Humic Substances and Soil and Water Environment. $12^{\text {th }}$ International Meeting of the International Humic Substances Society; 2004 July 26-30; São Pedro, Brazil: Embrapa Instrumentação Agropecuária. p. 244-246.

- Almendros G, González-Vila FJ, González-Pérez JA, Knicker H, Zancada MC, Polvillo O. 2005. Tentatively quantifying fire impact, organic carbon balance and thermal structural rearrangements by ${ }^{13} \mathrm{C}$ CPMAS NMR of whole soil samples from Continental Mediterranean forests. In: Proceedings of the $22^{\text {nd }}$ International Meeting on Organic Geochemistry (22nd IMOG); 2005 Sep 12-16; Seville, Spain.

- Almendros G. 2008a. Carbon sequestration in soil. In: Chesworth W, editor. Kluwer Encyclopedia of Soil Science. Dordretch: Springer. p. 315-323.

- Almendros G. 2008b. Humic substances. In: Chesworth W, editor. Kluwer Encyclopedia of Soil Science. Dordretch: Springer. p. 97-99.

- Almendros G, González-Vila FJ, Lankes U, Knicker H 2008. Structural domains in peat as revealed by physical fractionation, sequential chemolysis and ${ }^{15} \mathrm{~N}$ - and ${ }^{13} \mathrm{C}-\mathrm{CP}$ MAS NMR spectroscopies. Org Geochem. 39:972-976.

- Almendros G, González-Vila FJ, González-Pérez JA, Knicker H, De la Rosa JM. 2010a. Protocolos, técnicas analíticas e instrumentales para evaluar el impacto del fuego sobre la materia orgánica del suelo. In: Cerdà $A$, Jordán $A$, editors. Actualización en métodos y técnicas 
para el estudio de los suelos afectados por incendios forestales. Cap. 3.2. Valencia: Cátedra de Divulgació de la Ciència, Universitat de València, Fuegored 2010. p. 289-326.

- Almendros G, González-Vila FJ, Knicker H, Verdejo T, González-Pérez JA, Dettweiler C. 2010b. Reappraisal of water-repellence-inducing soil organic material in mineral soils after controlled thermal heating. In: Proceedings of the Jornadas Internacionales en Investigación y Gestión para la Protección del Suelo y Restauración de los Ecosistemas Afectados por Incendios Forestales. Fuegored 2010; 2010 Oct 6-8; Santiago de Compostela, Spain. p. 91-94.

- Almendros G, González-Vila FJ, González-Pérez JA, Knicker H, De La Rosa JM, Dettweiler C, Hernández Z. 2012. On the structural factors of soil humic matter related to soil water repellence in fire-affected soils. In: Geophysical Research Abstracts, Vol. 14; General Assembly of the European Geo-Sciences Union (EGU 2012); Vienna, Austria. EGU2012-8712-4.

- Arias ME, González-Pérez JA, González-Vila FJ, Ball AS. 2005. Soil health-a new challenge for microbiologists and chemists. Internat Microbiol. 8:13-21.

- Barreiro A, Martín A, Carballas T, Díaz-Raviña M. 2010. Response of soil microbial communities to fire and firefighting chemicals. Sci Total Environ. 408:6172-6178.

- Borken W, Matzner E. 2009. Reappraisal of drying and wetting effects on $\mathrm{C}$ and $\mathrm{N}$ mineralization and fluxes in soils. Global Change Biol. 15(4):808-824.

- Bowman DMJS, Balch JK, Artaxo P, Bond WJ, Carlson JM, Cochrane MA, D'Antonio CM, DeFries RS, Doyle JC, Harrison SP, Johnston FH, Keeley JE, Krawchuk MA, Kull CA, Marston JB, Moritz MA, Prentice IC, Roos Cl, Scott AC, Swetnam TW, Van Der Werf GR, Pyne SJ. 2009. Fire in the earth system. Science 324(5926):481-484.

- Bruun S, Jensen ES, Jensen LS. 2008. Microbial mineralization and assimilation of black carbon: Dependency on degree of thermal alteration. Org Geochem. 39:839845 .

- Caldararo N. 2002. Human ecological intervention and the role of forest fires in human ecology. Sci Total Environ. 292:141-165.

- Cerdà A. 2004. Soil erosion after forest fire in Spain: State-of-the-art. Geophys Res Abstr 6:07193.

- Cerdà A, Doerr SH. 2005. Influence of vegetation recovery on soil hydrology and erodibility following fire: An 11year investigation. Internat J Wildland Fire 14(4):423-443.

- Cerdà A, Mataix-Solera J, editors. 2009. Efectos de los incendios forestales sobre los suelos en España. El estado de la cuestión visto por los científicos españoles. Valencia: Càtedra de Divulgació de la Ciència, Universitat de Valencia. 529 pp.
- Cerdà A, Jordán A, editors. 2010. Actualización en métodos y técnicas para el estudio de los suelos afectados por incendios forestales. FUEGORED 2010. Valencia: Cátedra de Divulgació de la Ciència, Universitat de València. $521 \mathrm{pp}$.

- Certini G. 2005. Effects of fire on properties of forest soils: a review. Oecologia 143:1-10.

- Cheng C-H, Lehmann J, Thies JE, Burton SD, Engelhard $\mathrm{MH}$. 2006. Oxidation of black carbon by biotic and abiotic processes. Org Geochem. 37:1477-1488.

- Da Silva DM, Batalha MA. 2008. Soil-vegetation relationships in cerrados under different fire frequencies. Plant Soil 311(1-2):87-96.

- Dai X, Boutton TW, Glaser B, Ansley RJ, Zech W. 2005. Black carbon in a temperate mixed-grass savanna. Soil Biol Biochem. 37(10): 1879-1881.

- De Blas E, Rodríguez-Alleres M, Almendros G. 2010. Speciation of lipid and humic fractions in soils under pine and eucalyptus forest in Northwest Spain and its effect on water repellency. Geoderma 155:242-248.

- De Blas E, Almendros G, Sanz J. 2011. Molecular characterization of hydrophobic coatings and fixed lipids from extremely water repellent pine and eucalypt forest soils. In: Proceedings of the 6th International Symposium of Interactions of Soil Minerals with Organic Components and Microorganisms (ISMOM 2011, Soil Interfaces in a Changing World); 2011 Jun 26-Jul 1; Montpellier, France.

- De Blas E, Almendros G, Sanz J. 2012. Molecular characterization of lipid fractions from extremely water repellent forest soils in northwestern Spain (under revision).

- DeBano LF, Mann LD, Hamilton DA. 1970. Translocation of hydrophobic substances by burning organic litter. Soil Sci Soc Amer Proc. 34:130-133.

- Dettweiler C, Almendros G, González-Vila FJ, Knicker H. 2003a. Alterations of soil organic matter in mineral soils after controlled heating. In: Proceedings of the International Conference on Mechanisms and Regulation of Organic Matter Stabilisation in Soils; 2003 Oct 5-8; Munich, Germany. p. 54.

- Dettweiler C, Knicker H, González-Vila FJ, Almendros G, Zancada MC. 2003b. Monitoring the fire impact on soil through chromatographic analysis of the lipid fraction. In: Proceedings of the $3^{\text {rd }}$ Scientific Meeting of the Spanish Society of Chromatography and Related Techniques; 2003 Nov 19-21; Almería, Spain. p.149.

- Doerr SH, Shakesby RA, Walsh RPD. 2000. Soil water repellency: its causes, characteristics and hydro-geomorphological significance. Earth-Science Reviews 51:3335 .

- Efremova TT, Efremov SP. 2006. Pyrogenic transformation of organic matter in soils of forest bogs. Euras Soil Sci. 39:1297-1305. 
- Fernández I, Cabaneiro A, Carballas T. 2001. Thermal resistance to high temperatures of different organic fractions from soils under pine forests. Geoderma 104(34):281-298.

- Giovannini G, Lucchesi S. 1983. Effect of fire on hydrophobic and cementing substances of soil aggregates. Soil Sci. 136:231-236.

- Glaser B, Haumaier L, Guggenberger G, Zech W. 1998. Black carbon in soils: The use of benzenecarboxylic acids as specific markers. Org. Geochem. 29:811-819.

- González-Pérez JA, González-Vila FJ, Almendros G, Knicker H, Polvillo O, Salas F, Costa JC. 2002. Wildfire and black carbon production in Andalusian Mediterranean forest. In: Proceedings of the IV Internationa Conference on Forest Fire Research; 2002 Nov18-23; Coimbra, Portugal. p. 2.

- González-Pérez JA, González-Vila FJ, Almendros G, Knicker H. 2004. The effect of fire on soil organic matter-a review. Environ Internat. 30:855-870.

- González-Vázquez R. 2011. Impacto de los incendios forestales en la materia orgánica de los suelos: la composición de la fracción lipídica como índice del grado de recuperación de suelos quemados. Tesis Doctoral. Universidad de Sevilla.

- González-Vila FJ, Tinoco P, Almendros G, Martin F. 2001. Pyrolysis-GC-MS analysis of the formation and degradation stages of charred residues from lignocellulosic biomass. J Agric Food Chem. 49:1128-1131.

- González-Vila FJ, González JA, Polvillo O, Almendros G, Knicker H. 2002. Nature of refractory forms of organic carbon in soils affected by fires. Pyrolytic and spectroscopic approaches. In: Viegas DX, editor. Forest Fire Research and Wildland Fire Safety (CD-ROM), 5 pp. Rotterdam, The Netherlands: Millpress. 244 pp.

- González-Vila FJ, Almendros G. 2003. Thermal transformation of soil organic matter by natural fires and laboratory-controlled heatings. In: Ikan R, editor. Natural and Laboratory Simulated Thermal Geochemical Processes. Dordrecht: Kluwer Academic Publishing. p.153-200.

- González-Vila FJ, Almendros G, Knicker H, GonzálezPérez, JA. 2006a. Occurrence of stable $\mathrm{N}$-forms in chemically and physically altered peat samples as seen by ${ }^{15} \mathrm{~N}$ NMR. In: Proceedings of the General Assembly of the European Geosciences Union (EGU 2006); 2006 Apr 2-7; Vienna, Austria.

- González-Vila FJ, González-Pérez JA, Almendros G, Arias ME, Knicker H. 2006b. Appraisal of biogeochemical markers for the assessment of damage levels in soils affected by wildfires. In: Proceedings of the General Assembly of the European Geosciences Union (EGU 2006); 2006 Apr 2-7; Vienna, Austria. EGU06-A-01005.
- González-Vila FJ, Almendros G, González-Pérez JA, Knicker H, González-Vázquez R, Hernández Z, Piedra Buena A. 2009. Transformación de la materia orgánica del suelo por incendios naturales, calentamientos controlados en condiciones de laboratorio. In: Cerdà A, MataixSolera J, editors. Efectos de los Incendios Forestales sobre los Suelos en España. Laimprenta CG. p. 219-268.

- Guggenberger G, Rodionov A, Shibistova O, Grabe M, Kasansky OA, Fuchs H, Mikheyeva N, Zrazhevskaya G, Flessa H. 2008. Storage and mobility of black carbon in permafrost soils of the forest tundra ecotone in Northern Siberia. Global Change Biology 14:1367-1381.

- Hatten JA, Zabowski D. 2010. Fire severity effects on soil organic matter from a ponderosa pine forest: A laboratory study. Internat J Wildland Fire 19:613-623.

- Hernández T, García C, Reinhardt I. 1997. Short-term effect of wildfire on the chemical, biochemical and microbiological properties of Mediterranean pine forest soils. Biol Fertil Soils 25:109-116.

- Hernández Z, Almendros G. 2012. Biogeochemical factors related with organic matter degradation and $C$ storage in agricultural volcanic ash soils. Soil Biol Biochem. 44:130-142.

- Hockaday WC, Grannas AM, Kim S, Hatcher PG. 2006. Direct molecular evidence for the degradation and mobility of black carbon in soils from ultrahigh-resolution mass spectral analysis of dissolved organic matter from a fireimpacted forest soil. Org Geochem. 37:501-510.

- Iglesias T, Almendros G, Aroca MJ, Fernández Bermejo MC. 2008. The impact of recurrent wildfire on chemical properties of forest soils under pine from central Spain. In: Geophysical Research Abstracts, Vol. 10; General Assembly of the European Geosciences Union (EGU 2008); 2008 Apr 13-18; Vienna, Austria. EGU2008-A-11968.

- Kiersch K, Kruse J, Eckhardt K-U, Fendt A, Streibel T, Zimmermann R, Broll G, Leinweber P. 2012. Impact of grassland burning on soil organic matter as revealed by a synchrotron- and pyrolysis-mass spectrometry-based multi-methodological approach. Org Geochem. 44:8-20.

- Knicker H, Almendros G, González-Vila FJ, Martín F, Lüdemann H-D. $1996 .{ }^{13} \mathrm{C}$ - and ${ }^{15} \mathrm{~N}-\mathrm{NMR}$ spectroscopic examination of the transformation of organic nitrogen in plant biomass during thermal treatment. Soil Biol Biochem. 28:1053-1060.

- Knicker H, González-Vila FJ, Polvillo O, González JA, Almendros G. 2003a. Distribution of charred organic matter in the humic fractions of a fire affected Xerochrept. In: Proceedings of the CarboEurope Conference "The continental carbon cycle"; 2003 Mar 19-21; Lisbon, Portugal.

- Knicker H, González-Vila FJ, Polvillo O, González JA, Almendros G. 2003b. Wild-fire effects on the quantity and quality of soil organic matter as revealed by solid-state NMR and pyrolysis-GC/MS. In: Proceedings of the $21^{\text {st }}$ 
International Meeting on Organic Geochemistry; 2003 Sep 8-12; Kraków, Poland. P II/164.

- Knicker H, Abelmann K, González Vila FJ, Almendros G, Kögel-Knabner I. 2004. Pyrogenic humic substances - How reliable is their analysis with NMR spectroscopy? In: Martin-Neto L, Bastos Pereira Milori DM, Lopes da Silva WT, editors. Humic Substances and Soil and Water Environment. $12^{\text {th }}$ International Meeting of the International Humic Substances Society; 2004 July 26-30; São Pedro, Brazil: Embrapa Instrumentação Agropecuária. p. 660-663.

- Knicker H, González-Vila FJ, Polvillo O, González JA, Almendros G. 2005a. Fire-induced transformation of Cand $\mathrm{N}$ - forms in different organic soil fractions from a Dystric Cambisol under a Mediterranean pine forest (Pinus pinaster). Soil Biol Biochem. 37:701-718.

- Knicker K, Totsche KU, Almendros G, González-Vila FJ. 2005b. Condensation degree of burnt peat and plant residues and the reliability of solid-state VACP MAS ${ }^{13} \mathrm{C}$ NMR spectra obtained from pyrogenic humic material. Org Geochem. 36:1359-1377.

- Knicker H, Almendros G, González-Vila FJ, GonzálezPérez JA, Polvillo O. 2006a. Characteristic alterations of quantity and quality of soil organic matter caused by forest fires in continental Mediterranean ecosystems: a solid-state C-13 NMR study. Eur J Soil Sci. 57:558-569.

- Knicker H, González-Vila FJ, Almendros G, GonzálezPérez JA, Polvillo O. 2006b. Chemical changes of soil organic matter following burning. In: Proceedings of the General Assembly of the European Geosciences Union (EGU 2006); 2006 Apr 2-7; Vienna, Austria. EGU06A-02334.

- Knicker H, González-Vila FJ, González-Pérez JA, Almendros G. 2006c. Where is all the charcoal gone? structure and stability of charred plant residues and their role in refractory soil organic matter accumulation. In: Proceedings of the 18th World Congress of Soil Science; 2006 Jul 9-15; Philadelphia, Pennsylvania, USA.

- Knicker H, Hilscher A, González-Vila FJ, Almendros G. 2007. A new conceptual model for the structural properties of char produced during vegetation fires. Org Geochem. 39:935-939.

- Knicker H, González-Vila FJ, Clemente-Salas L, Almendros G. 2010. Carbono pirogénico en suelos afectados por incendios. In: Abstracts del IV Congreso Ibérico de la Ciencia del Suelo (CISC2010); 2010 Sep 21-24; Granada, Spain.

- Knicker H, González-Vila FJ, Clemente-Salas L, Almendros G, González-Vázquez R. 2011. Turnover of charcoal in fire-prone mineral soils of Southern Europe. In: Proceedings of the 6th International Symposium of Interactions of Soil Minerals with Organic Components and Microorganisms (ISMOM 2011, Soil Interfaces in a Changing World); 2011 Jun 26-Jul 1; Montpellier, France.
- Kuhlbusch TAJ, Crutzen PJ. 1995. Toward a global estimate of black carbon in residues of vegetation fires representing a sink of atmospheric $\mathrm{CO}_{2}$ and a source of $\mathrm{O}_{2}$. Global Biogeochemical Cycles 9(4):491-501.

- Kuhn TK, Krull ES, Bowater A, Grice K, Gleixner G. 2010. The occurrence of short chain n-alkanes with an even over odd predominance in higher plants and soils. Org Geochem. 41:88-95.

- Kumada K, Hurst HM. 1967. Green humic acid and its possible origin as a fungal metabolite. Nature 214:631633.

- Laird DA, Chappell MA, Martens DA, Wershaw RL, Thompson M. 2008. Distinguishing black carbon from biogenic humic substances in soil clay fractions Geoderma 143:115-122.

- Levine JS, editor. 1996. Biomass Burning and Global Change. Vols. 1 and 2. Cambridge, Massachusetts: The MIT Press.

- Marcos E, Tárrega R, Luis E. 2007. Changes in a Humic Cambisol heated $\left(100-500{ }^{\circ} \mathrm{C}\right)$ under laboratory conditions: The significance of heating time. Geoderma 138:237-243.

- Martín A, Díaz-Raviña M, Carballas T. 2009. Evolution of composition and content of soil carbohydrates following forest wildfires. Biol Fertil Soils 45(5):511-520.

- Mataix-Solera J, Cerdà A, Arcenegui V, Jordán A, Zavala LM. 2011. Fire effects on soil aggregation: A review. Earth-Science Reviews 109(1-2):44-60.

- Mataix-Solera J, Arcenegui V, Tessler N, Zornoza R, Wittenberg L, Martínez C, Caselles P, Pérez-Bejarano A, Malkinson D, Jordán MM. 2012. Soil properties as key factors controlling water repellency in fire-affected areas: Evidences from burned sites in Spain and Israel. Catena (in press).

- Matsuda K, Schnitzer M. 1972. The permanganate oxidation of humic acids extracted from acid soils. Soil Sci. 114:185-193.

- Orioli GA, Curvetto NR. 1978. The effect of fire on soil humic substances. Plant Soil 50:91-98.

- Pastorova I, Botto RE, Arisz PW, Boon JJ. 1994. Cellulose char structure: a combined analytical Py-GC-MS, FTIR, and NMR study. Carbohydr Res 262:27-47.

- Piedra- Buena A, Almendros G, González-Vila FJ. 2009a. Structural transformations of humic matter in terms of fire intensity as revealed by changes in the assemblages of pyrolytic products. In: Proceedings of the II Jornadas Internacionales "Efectos de los Incendios Forestales Sobre los Suelos"; 2009 Nov 4-6; Sevilla, Spain. 
- Piedra- Buena A, González-Vila FJ, González-Pérez JA, Almendros G. 2009b. Signature of nitrogen compounds responsive for changes in $\mathrm{C}$ and $\mathrm{N}$ forms in peat subjected to progressive thermal stress. In: Proceedings of the $12^{\text {th }}$ Nordic-Baltic-IHSS Symposium on Natural Organic Matter in Environment and Technology; 2009 Jun 14-17; Tallinn, Estonia. p. 77

- Piedra- Buena A, Almendros G, González-Vila FJ, González-Pérez JA, Knicker H. 2010. Transformations in carbon and nitrogen forms in peat subjected to progressive thermal stress as revealed by analytical pyrolysis. Chem Ecol. 26:361-370.

- Poirier N, Derenne S, Balesdent J, Rouzaud JN, Mariotti A, Largeau C. 2002. Abundance and composition of the refractory organic fraction of an ancient, tropical soil (Pointe Noire, Congo). Org Geochem. 33(3):383-391.

- Ponomarenko EV, Anderson DW. 2001. Importance of charred organic matter in Black Chernozem soils of Saskatchewan. Can J Soil Sci. 81:285-297.

- Preston CM, Schmidt MWI. 2006. Black (pyrogenic) carbon: A synthesis of current knowledge and uncertainties with special consideration of boreal regions. Biogeosciences 3:397-420.

- Pyne SJ. 2001 The fires this time, and next. Science 294(5544):1005-1006.

- Reeves III JB, McCarty GW, Rutherford DW, Wershaw RL. 2008. Mid-infrared diffuse reflectance spectroscopic examination of charred pine wood, bark, cellulose, and lignin: Implications for the quantitative determination of charcoal in soils. Appl Spectrosc. 62:182-189.

- Richardson DM, editor. 1998. Ecology and Biogeography of Pinus. Cambridge: Cambridge Univ. Press. 530 pp.

- Rovira P, Duguy B, Vallejo VR. 2009. Black carbon in wildfire-affected shrubland Mediterranean soils. J Plant Nutr Soil Sci. 172(1):43-52.

- Rovira P, Romanyà J, Duguy B. 2012. Long-term effects of wildfires on the biochemical quality of soil organic matter: A study on Mediterranean shrublands. Geoderma (article in press).

- Rumpel C, Ba A, Darboux F, Chaplot V, Planchon O. 2009. Erosion budget and process selectivity of black carbon at meter scale. Geoderma 154(1-2):131-137.

- Savage SM, Osborn J, Letey J, Heaton C. 1972. Substances contributing to fire-induced water repellency in soil. Soil Sci Soc Amer Proc. 36:674-678.

- Savage SM. 1974. Mechanism of fire-induced water repellency in soil. Soil Sci Soc Amer Proc. 38:652-657.

- Schnitzer M, Khan SU. 1978. Soil organic matter. Amsterdam: Elsevier.
- Shindo H, Ushijima N, Amano Y. 2003. Comparison of elementary and humus composition of woody plants before and after burning. Soil Sci Plant Nutr. 49:685-693.

- Skjemstad JO, Taylor JA, Smernik RJ. 1999. Estimation of charcoal (char) in soils. Commun Soil Sci Plant Anal. 30: 2283-2298.

- Spanish Ministry of Environment. 2005. Los incendios forestales en España durante el año 2005. Madrid: Ministerio de Medio Ambiente. 120 pp.

- Steiner C, Teixeira WG, Lehmann J, Nehls T, De Macêdo JLV, Blum WEH, Zech W. 2007. Long term effects of manure, charcoal and mineral fertilization on crop production and fertility on a highly weathered Central Amazonian upland soil, Plant Soil 291(1-2): 275-290.

- Stevenson FJ. 1982. Humus Chemistry. Genesis. Composition. Reactions. New York: Wiley. 443 pp.

- Tinoco P. 2000. Caracterización molecular de la materia orgánica de suelos afectados por distintos tipos de degradación en la Comunidad de Madrid. Tesis Doctoral. Universidad Autónoma de Madrid.

- Tinoco P, Almendros G, Sanz J, González-Vázquez R, González-Vila FJ. 2006. Molecular descriptors of the effects of fire on continental Mediterranean soils under pine forest. Org Geochem. 37:1995-2018.

- Vergnoux A, Guiliano M, Di Rocco R, Domeizel M Théraulaz F, Doumenq P. 2011. Quantitative and mid-infrared changes of humic substances from burned soils. Environ Res. 111:205-214.

- Viro PJ. 1974. Effects of Forest Fire on Soil. In: Kozlowski TT, Ahlgren CE, editors. Fire and Ecosystems. New York: Academic Press. p. 7-45. 